\title{
Postbiotics-parabiotics: the new horizons in microbial biotherapy and functional foods
}

\author{
Basavaprabhu H. Nataraj ${ }^{1}$, Syed Azmal Ali ${ }^{2}$, Pradip V. Behare ${ }^{1 *}$ and Hariom Yadav ${ }^{3^{*}}$ (D)
}

\begin{abstract}
Probiotics have several health benefits by modulating gut microbiome; however, techno-functional limitations such as viability controls have hampered their full potential applications in the food and pharmaceutical sectors. Therefore, the focus is gradually shifting from viable probiotic bacteria towards non-viable paraprobiotics and/or probiotics derived biomolecules, so-called postbiotics. Paraprobiotics and postbiotics are the emerging concepts in the functional foods field because they impart an array of health-promoting properties. Although, these terms are not well defined, however, for time being these terms have been defined as here. The postbiotics are the complex mixture of metabolic products secreted by probiotics in cell-free supernatants such as enzymes, secreted proteins, short chain fatty acids, vitamins, secreted biosurfactants, amino acids, peptides, organic acids, etc. While, the paraprobiotics are the inactivated microbial cells of probiotics (intact or ruptured containing cell components such as peptidoglycans, teichoic acids, surface proteins, etc.) or crude cell extracts (i.e. with complex chemical composition)". However, in many instances postbiotics have been used for whole category of postbiotics and parabiotics. These elicit several advantages over probiotics like; (i) availability in their pure form, (ii) ease in production and storage, (iii) availability of production process for industrial-scale-up, (iv) specific mechanism of action, (v) better accessibility of Microbes Associated Molecular Pattern (MAMP) during recognition and interaction with Pattern Recognition Receptors (PRR) and (vi) more likely to trigger only the targeted responses by specific ligand-receptor interactions. The current review comprehensively summarizes and discussed various methodologies implied to extract, purify, and identification of paraprobiotic and postbiotic compounds and their potential health benefits.
\end{abstract}

Keywords: Probiotics, Postbiotics, Paraprobiotics, Functional foods, Health benefits

\section{Introduction}

Food is a paramount basic need of life that clinches the nutritional requirement of an individual. The nutrients like fats, carbohydrates, and proteins pledge energy for growth and maintenance, whereas non-nutrient factors (fiber, phytochemicals, antioxidants, vitamins, minerals, probiotics, prebiotics, etc.) augment human health

\footnotetext{
*Correspondence: pradip_behare@yahoo.com; hyadav@wakehealth.edu 1 Technofunctional Starters Lab, National Collection of Dairy Cultures (NCDC), Dairy Microbiology Division, ICAR-National Dairy Research Institute, Karnal, Haryana 132001, India

${ }^{3}$ Department of Internal Medicine-Molecular Medicine and Microbiology and Immunology, Wake Forest School of Medicine, Biotech Place, Room 2E-034, 575 North Patterson Ave, Winston-Salem, NC 27101, USA Full list of author information is available at the end of the article
}

by positively modulating the host physiology and global epigenetic imprints [1-4]. Dietary intake of selected categories of foods comprising active components regulate the disease controlling mechanisms either as prophylactics or therapeutics, and such foods are typically called as nutraceuticals or foodiceuticals or functional foods or medifoods [5]. An intense innovation in the field of functional food has pawed way to generate an extensive range of health-promoting bioactive compounds such as probiotics, prebiotics, phytochemicals or herbs, natural antioxidants, bioactive peptides, etc. [6]. The manifestations of these active biologicals naturally in food or external fortification flag the food functional [7, 8]. Japan is the first country to propose legislation for the specific

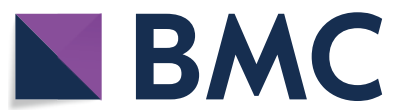

(c) The Author(s) 2020. This article is licensed under a Creative Commons Attribution 4.0 International License, which permits use, sharing, adaptation, distribution and reproduction in any medium or format, as long as you give appropriate credit to the original author(s) and the source, provide a link to the Creative Commons licence, and indicate if changes were made. The images or other third party material in this article are included in the article's Creative Commons licence, unless indicated otherwise in a credit line to the material. If material is not included in the article's Creative Commons licence and your intended use is not permitted by statutory regulation or exceeds the permitted use, you will need to obtain permission directly from the copyright holder. To view a copy of this licence, visit http://creativeco mmons.org/licenses/by/4.0/. The Creative Commons Public Domain Dedication waiver (http://creativecommons.org/publicdomain/ zero/1.0/) applies to the data made available in this article, unless otherwise stated in a credit line to the data. 
regulatory approval procedures of functional foods that were implemented as Food for Specific Health Uses (FOSHU) $[9,10]$. Thereafter, several other countries have also structured their regulatory enforcement actions and civil litigations to govern the regulatory issues regarding functional foods such as US Federal Food and Drug Administration in the United States (USA), Food Safety and Standards Authority of India (FSSAI) in India, China Food and Drug Administration (CFDA) in China, European Union (EU) in Europe, National Sanitary Surveillance Agency (NSSA) in Brazil, etc. [11]. The functional foods can be defined as "any food that has a positive impact on an individual's health, physical performance, or state of mind, in addition to its nutritious value" [9]. Also, it should serve to regulate a particular body process, such as enhancement of biological defense mechanisms, prevention of specific diseases, control of physical and mental disorders, and slowing of the aging process [9]. However, these functional foods can be further categorized as natural, transformed, fortified, and enhanced foods [9]. The rapid industrialization and modernization coupled with plummeting in the rate of consumption of health-promoting natural foods have witnessed the emergence of different health complications at an early age of human life [12-14]. Fascinatingly, consumer awareness and acceptance of functional foods to counteract lifestyle diseases have been recently amplified. This consumer interest is indeed driving the global functional food sector with an economic momentum of more than US $\$ 180$ billion with the global annual demand for functional foods has anticipated rising at $8 \%$ [15].

Probiotics are among the amply studied and applied functional food ingredients. Probiotics are defined as "live microorganisms that, when administered in adequate amounts, confer a health benefit on the host" [16]. Lactobacillus and Bifidobacterium are the most studied probiotic genera. However, Bacteroides and Clostridium genera are emerging as next-generation probiotics irrespective of their safety issues [17]. To address such issues, the European Food Safety Authority (EFSA) has granted the Qualified Presumption of Safety (QPS) status to only a total of 32 Lactobacillus species for human applications considering their safety perspectives [18]. Hitherto, probiotics have been investigated for their ability to surpass gut functioning, alleviation of lactose intolerance, enhancement of immune function, anti-carcinogenic, anti-diabetic, anti-oxidative, anti-aging, antimicrobial, and anti-biofilm actions [19, 20].

Despite several health benefits, investigations on probiotics have highlighted few limitations such as unknown molecular mechanisms, strain-specific behaviors, shortlived, niche-specific action of probiotics (allochthonous or autochthonous), developing antibiotic resistance, virulence genes transfer, ambiguous beneficial effects, issues about the maintenance of viability and stability in the production process, a hindrance for colonization of commensal gut microflora, ability to cause opportunistic infections, inflammatory response infective endocarditis, sepsis, bacterial translocation to tissue or blood, and bacteremia in immunocompromised individuals are significant bottlenecks [21-23]. The low concentrations of probiotic derived biologically active compounds found in specific target sites in the course of traditional application of live probiotic microorganisms (live biotherapeutics) were found ineffective at in vivo conditions $[24,25]$. On the other note, live probiotics have been reported to be affected by various host-specific factors in the gastrointestinal tract (GIT) that subsequently activate several bacterial genes for degradation and production of different nutrients by various metabolic pathways [26, 27]. To address such issues, postbiotic components derived from probiotics are probably favorable and promising alternative supplements for human health and wellness thereof.

\section{Concepts and definition}

Several investigators have proposed different terminologies to describe postbiotics and paraprobiotics such as non-viable probiotics, inactivated probiotics, non-biotics, ghost probiotics, and metabiotics [24, 28, 29]. Of note, paraprobiotics have been defined alike the Food and Agriculture Organization/World Health Organization $(\mathrm{FAO} / \mathrm{WHO})$ definition of probiotics with minor modifications as "inactivated (non-viable) microbial cells, which, when administered in sufficient amounts, confer benefits to consumers" [30].

However, the verbal inconsistencies in defining postbiotics were streamlined by a recent opinion article [31]. Accordingly, (i) POSTBIOTICS may be defined as "non-viable bacterial products or metabolic products from microorganisms that have biological activity in the host (ii) PARAPROBIOTICS (also called ghost or inactivated probiotics) that are "non-viable microbial cells (either intact or broken) or crude cell extracts which when administered (either orally or topically) in adequate amounts, confer a benefit on the human or animal consumer"; and (iii) PROBIOCEUTICALS/PROBIOTACEUTICALS which defines probiotic derived factors such as reuterin from Lactobacillus reuteri.

Most importantly, the latest scientific literature has highlighted the widely accepted definition of paraprobiotics/ghosh probiotics as "the inactivated/dead/ non-viable microbial cells of probiotics (intact or ruptured containing probiotic cell components upon lysis) or crude cell extracts (i.e. with complex chemical composition)" [32]. By contrast, postbiotics are the complex mixture of healthy metabolic products or secreted 
components of probiotics in cell-free supernatants such as enzymes, secreted proteins, short chain fatty acids, vitamins, amino acids, peptides, organic acids, etc. [33, 34]. Although the tentative term postbiotics has been widely used so far, hitherto there is no definition recommended by international regulatory bodies or scientific associations.

Since the specific action of postbiotics relies on definite dosage levels, most studies have failed to fix a specific dose of postbiotics/paraprobiotics to ensure the beneficial effects alike probiotics at $10^{9}$ viable cells. To investigate the effectiveness of postbiotics, currently, there have been a handful of comparative studies conducted at the in vitro and in vivo levels, and such studies suggest the similar potentialities of postbiotics over the probiotics in terms of demonstrating various health benefits on the host [35-37]. Singh et al. have reported an excellent antagonistic knack of paraprobiotics (heat-killed form) over the live probiotic bacteria against enteropathogens [38]. Moreover, the outcome of a recent literature survey by Pique and coworkers [39] underscores that postbiotics exert several pharmacodynamic features over live bacteria as enlisted below,

1) No risk of bacterial translocation from the gut lumen to blood among vulnerable and immunocompromised subjects.

2) No chances of acquisition and transfer of antibiotic resistance genes.

3) More natural to extract, standardize, transport, and store.

4) Loss of viability by cell lysis can produce further beneficial effects.

5) Enhanced interaction of every released molecule from the disrupted cells with the epithelial cells more directly.

\section{The forms of postbiotics and paraprobiotics}

The various postbiotic molecules include metabolic byproducts of live probiotic bacteria such as cell-free supernatant, vitamins, organic acids, short-chain fatty acids, secreted proteins/peptides, bacteriocins, neurotransmitters, secreted biosurfactants, amino acids, flavonoids derived postbiotics (desaminotyrosine, equol daidzein, daidzein, norathyriol), terpenoids derived postbiotics (genipin, paeoniflorin, paeoni lactone glycosides, paeonimetabolin I, II, III), phenolic-derived postbiotics (equol, urolithins, valerolactones, enterolactone, enterodiol, 8-prenylnaringenin) etc. [40-42]. Whereas, the paraprobiotics constitutes inactivated/dead/non-viable microbial cells of probiotics as intact or ruptured containing cell components of probiotic cells upon lysis such as teichoic acids, peptidoglycan-derived muropeptides, surface protruding molecules (pili, fimbriae, flagella), polysaccharides like exopolysaccharides, cell surface-associated proteins, cell wall-bound biosurfactants, teichoic acids, etc. [24, 43]. The use of purified postbiotic components or individual cellular components for therapeutic studies targeting a particular disease helps to rule out the specific underlying molecular mechanisms displayed by each molecule. However, to study the same in probiotics may results in unclear and multiple outcomes due to complex bacterial architecture/morphology. Therefore, various postbiotic molecules have drawn attention due to their known chemical structure, long storage stability, and the ability to trigger the various mechanisms in controlling inflammation, adhesion of pathogens to GIT, obesity, hypertension, coronary artery diseases (CVD), cancer, and oxidative stress (Fig. 1). Fascinatingly, postbiotic preparations have also granted patents as bio-therapeutics for a specific health claim "immune-modulation" [44, 45]. Similarly, metabolites of lactic acid bacteria (postbiotics) have granted patents as anti-tumour agents and feed additives for monogastric animals [46-48].

\section{Non-viable probiotics}

The non-viable probiotics are the inactivated or dead cells of probiotics. The inactivation of live bacteria can be achieved by various methods viz. heat treatment, chemicals (e.g., formalin), gamma or ultraviolet irradiation, and sonication, however, most commonly, heat treatment remains the method of choice for inactivation [32]. Nevertheless, the mode of inactivation by different methods, their effect on cellular structural components, and their influence on biological activities remain non-identical [49]. Heat treatments comprise a wide range of timetemperatures combinations to ensure the complete killing of bacteria in the suspension (Fig. 2). The inactivation can also be achieved by a combination of tyndallization and cell freezing process. In a study, the bacterial heatkilled suspension was prepared by heating cell suspension $\left(10^{9} \mathrm{CFU} / \mathrm{mL}\right)$ to $100^{\circ} \mathrm{C} / 30 \mathrm{~min}$, and the lethal effect was confirmed by pour plating [50]. Regarding the confirmation of heat-induced lethal effect and to understand the heat-induced changes on structural confirmations of various biomolecules, Attenuated Total ReflectionFourier-transform Infrared Spectroscopy (ATR-FTIR) technique was successfully employed in a study by considering the specific peak at $1635 \mathrm{~cm}^{-1}$ (amides of proteins and peptides) [51].

It is important to note that non-viable cells maintained their potentiality to deliver beneficial effects on the host at the intestinal level in vivo, thus aid the development of safer preparations with more optimal pharmaceutical properties [37, 52]. Heat-killed probiotics 


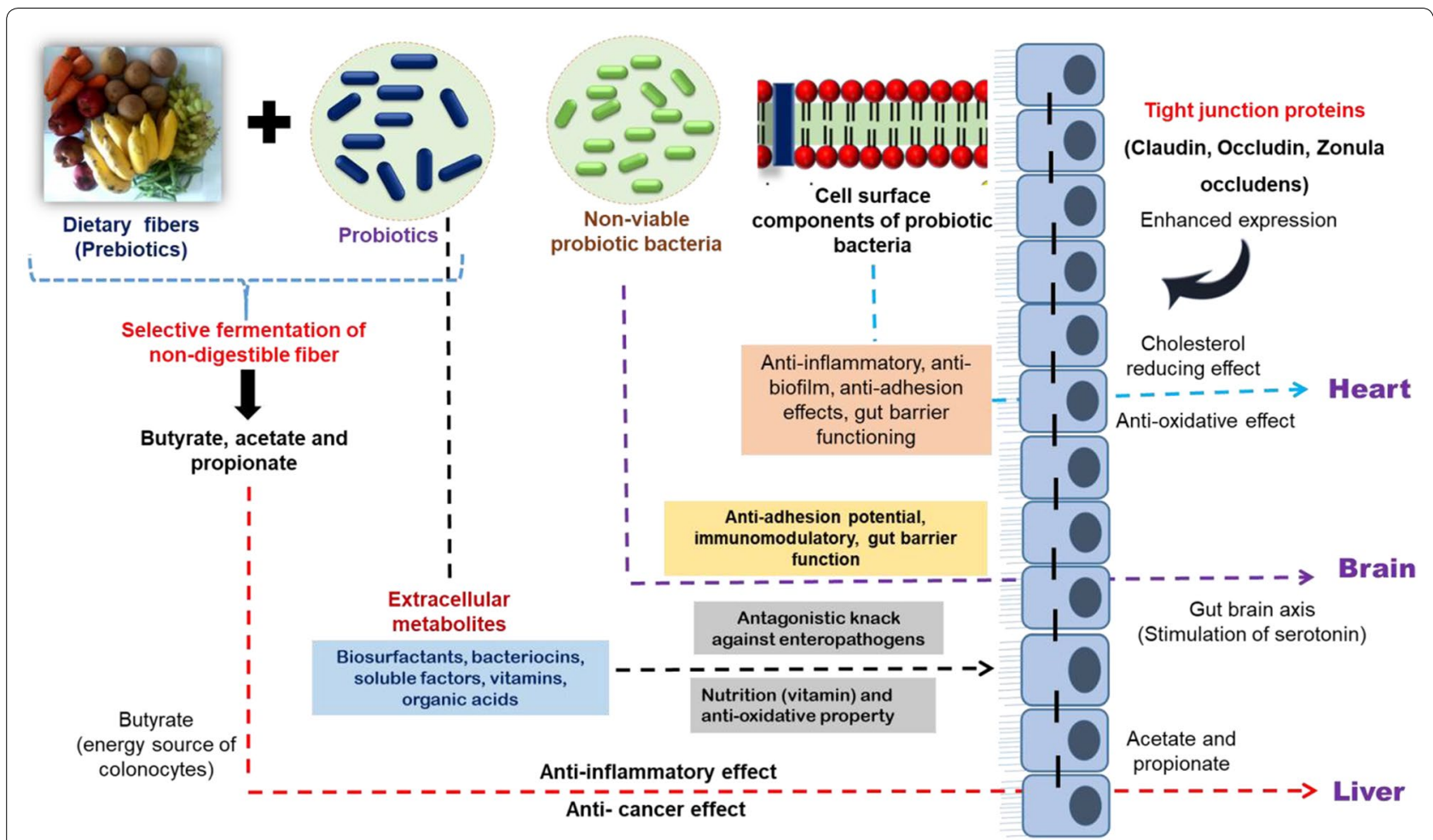

Fig. 1 Schematic representation of various health benefits of postbiotic molecules

revealed anti-adhesion (competition for adhesion sites) ability against various enteropathogens on the Caco- 2 experimental model [38]. This promising potentiality of heat-killed probiotics may indicate the ability to fight against diarrheal and food-borne pathogens in terms of their ability to compete for adhesion sites on gut enterocytes. Additionally, several heat-killed probiotics strains of Lactobacillus have demonstrated the anti-inflammatory (ability to suppress the inflammatory markers like IL-6, TNF- $\alpha$ and to enhance antiinflammatory cytokines viz. IL-10) and anti-oxidative (ability to scavenge the free radicals) effects at in vitro and in vivo experimental models $[35,53]$. On the other hand, probiotic heat-killed preparation had a substantial influence over serotonin secretion in the gut (gutbrain axis) [54]. A study by Saito et al. demonstrated that oral administration of heat-killed preparations of L. brevis $\mathrm{SBC} 8803$ to rats upregulates the acyl ghrelin concentration that in turn increased the ratio of acyl to des-acyl (inactive) ghrelin in blood. Apart from this, heat-killed cells also enhanced the expression of the Syt3 (synaptotagmin 3) gene related to ghrelin exocytosis in primary mouse stomach cells [55]. These findings suggest that not only live bacteria but also their heat-killed cells have the caliber to modulate host physiology. Moreover, there have been several lines of evidence currently available to demonstrate the similar mode of action of heat-killed probiotics vis-à-vis viable cells $[36,52,56]$.

\section{Biosurfactants}

Biosurfactants (BS) are the diverse polymeric molecules synthesized during the late log or early stationary phase of the growth cycle of an organism and are secreted extracellularly or cell wall-bound. BS assists the own cell in (i) nutrient uptake by increasing the surface area (ii) hydrophobic substrate metabolism (iii) cellular defense mechanism [57, 58]. Amongst the plethora of BS, few representatives viz. glycolipids, lipopeptides, phospholipids, neutral lipids, polysaccharide-protein complexes, and free fatty acids have been well documented $[59,60]$. BS are the amphiphilic molecules comprising hydrophobic (fatty acids or hydrocarbon chain) and hydrophilic (polysaccharide or peptides or acids) moieties to provide surface-active and emulsification properties that reduce the interfacial tension at the surface. This amphiphilic property of BS assists in the disruption of pre-formed biofilms or preventing the onset of biofilm formation by pathogenic microorganisms. Also, the wetting, foaming, and emulsification properties hurdle the bacteria to adhere, establish, and subsequently to communicate in the biofilms [61]. Studies have defined the possible insights on 


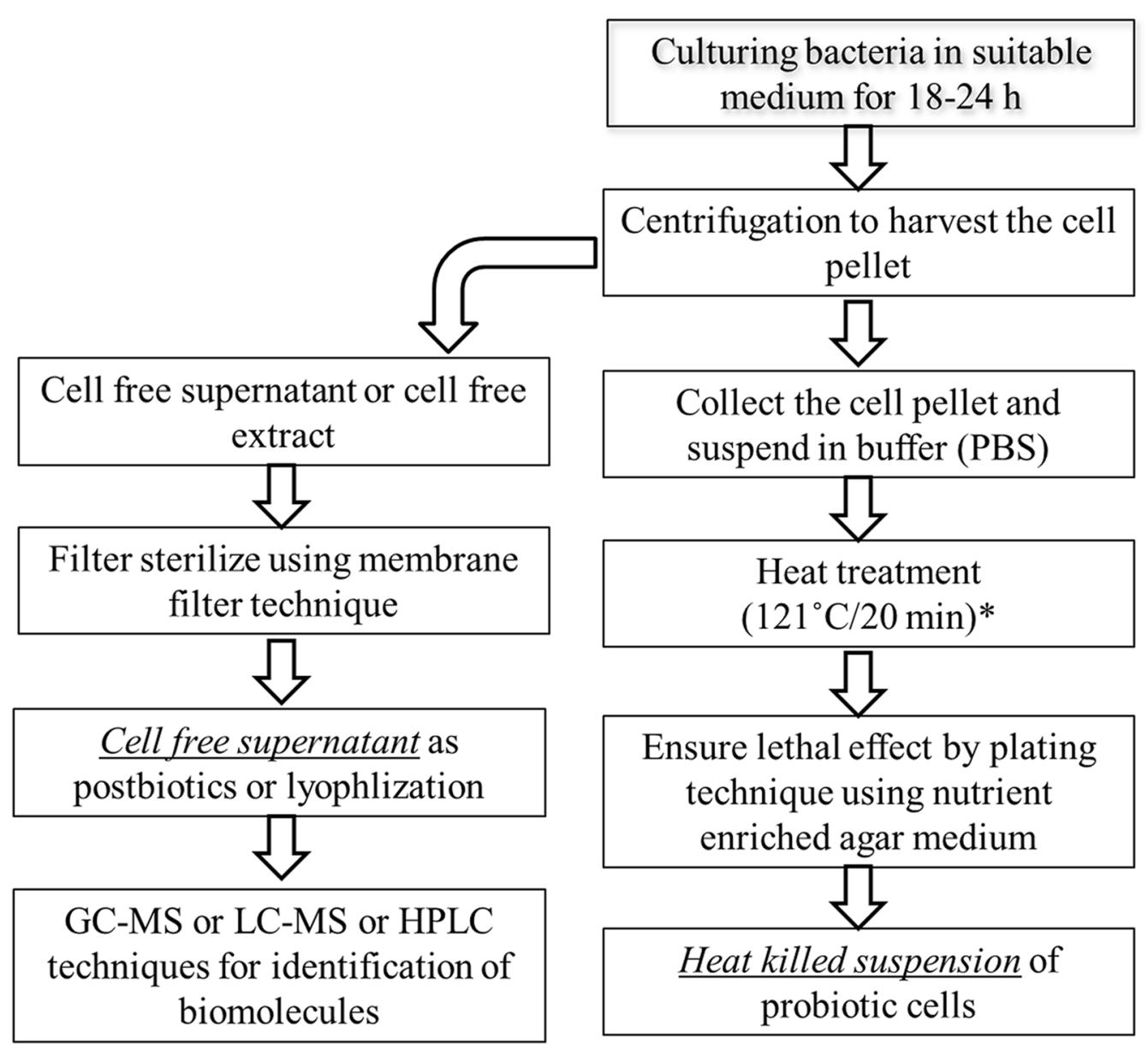

Fig. 2 Process flow line for production and characterization of heat killed cells and cell free supernatant [170]. ${ }^{*}$ denote that the use of different time-temperature combinations to ensure complete lethal effect)

antagonistic actions of BS agaisnt bacterial cells which include (i) the interaction of hydrophobic moieties of BS with membrane lipid to affect membrane integrity by pore formation (ii) direct interaction with the membrane lipids to trigger inhibition of the membrane-confined enzyme to cause outflow of intracellular cytoplasmic components $[62,63]$. The BS extraction methodology involves the solvent extraction principle (Fig. 3). The use of chloroform and methanol $(2: 1, \mathrm{v} / \mathrm{v})$ helps to recover both non-polar and polar molecules, respectively, from the bacterial fermentate. This method recovers both intracellular and cell-wall bound BS [64]. Furthermore, the characterization of extracted BS can be achieved by FTIR, Nuclear Magnetic Resonance (NMR), and other chromatographic techniques like Gas ChromatographyMass Spectrometry (GC-MS), Liquid ChromatographyMass Spectrometry (LC-MS). To minimize the cost of production, researchers have exploited agricultural by-products based medium (substrate) which has markedly hiked the productivity of biosurfactants. Hence, technology interventions to scale-up such methodologies would perhaps overcome the cost constraint for industrial partners to implement the production process [65].

BS offers several advantages over commercial detergents such as food grade, higher biodegradability, low toxicity, stability at various processing parameters like $\mathrm{pH}$, temperature, and salt concentrations $[66,67]$. However, few factors like feasibility, low yield, high cost of production are currently restricting production at commercial scale. Biotechnological intervention in strain improvement and optimization of agro-by-products based media may overcome the aforementioned drawbacks. Despite such limitations, rhamnolipids, sophorolipids, and mannosyl erythritol lipids (MELs) have been reported to produce at the commercial scale [68]. As far as food, pharmaceutical, and biomedical applications are concerned, the properties like emulsion stabilization, anti-adhesion, anti-biofilm, anti-cancer, anti-viral, immunomodulatory and antimicrobial abilities have been exploited [69] (Table 1). 


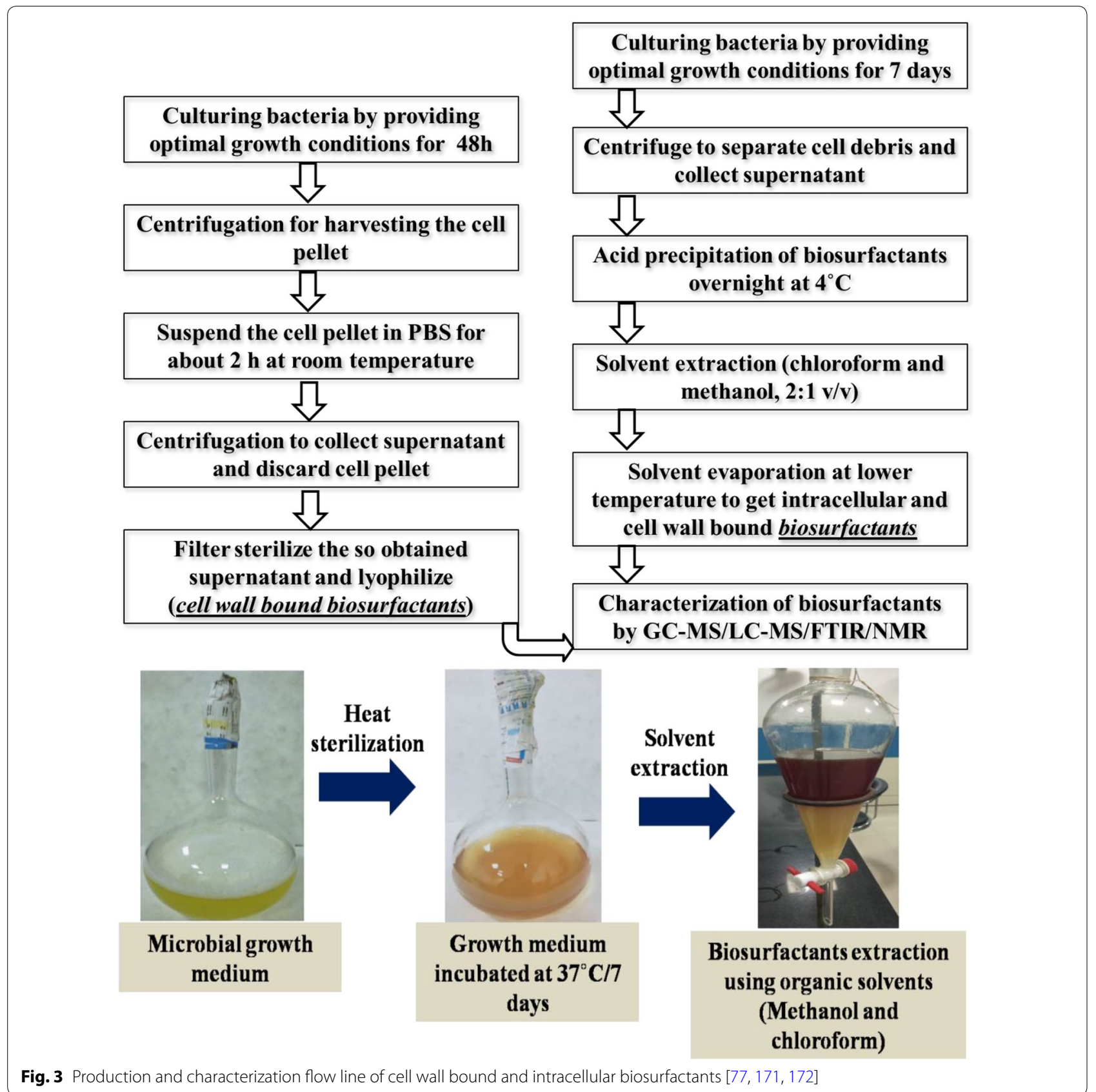

\section{Exopolysaccharides}

Exopolysaccharides (EPS) are extracellular biopolymer synthesized or secreted by microorganisms during their growth; they widely vary in their degree of branching from linear molecules to highly branched molecules, and in monosaccharide composition [70]. Based on the monosaccharide composition, EPS is further classified into homo-polysaccharide having identical monosaccharide units (e.g. cellulose and dextran) and hetero-polysaccharide with different monosaccharides (e.g. xanthan) [71].
Hitherto, ample lactic cultures (Lactobacillus fermentum, L. rhamnosus, Streptococcus thermophilus, Pediococcus pentosaceus, L. delbrueckii subsp. bulgaricus, Leuconostoc species, etc.) have reported synthesizing EPS [72-74]. Nevertheless, the production of EPS is highly strainspecific behavior and depends on various factors like the composition of the medium, age of the cell, $\mathrm{pH}$, and temperature [75]. The EPS of selected strains of dairy starter cultures is indeed a boon to the dairy industry as EPS has a strong command over the rheological properties 


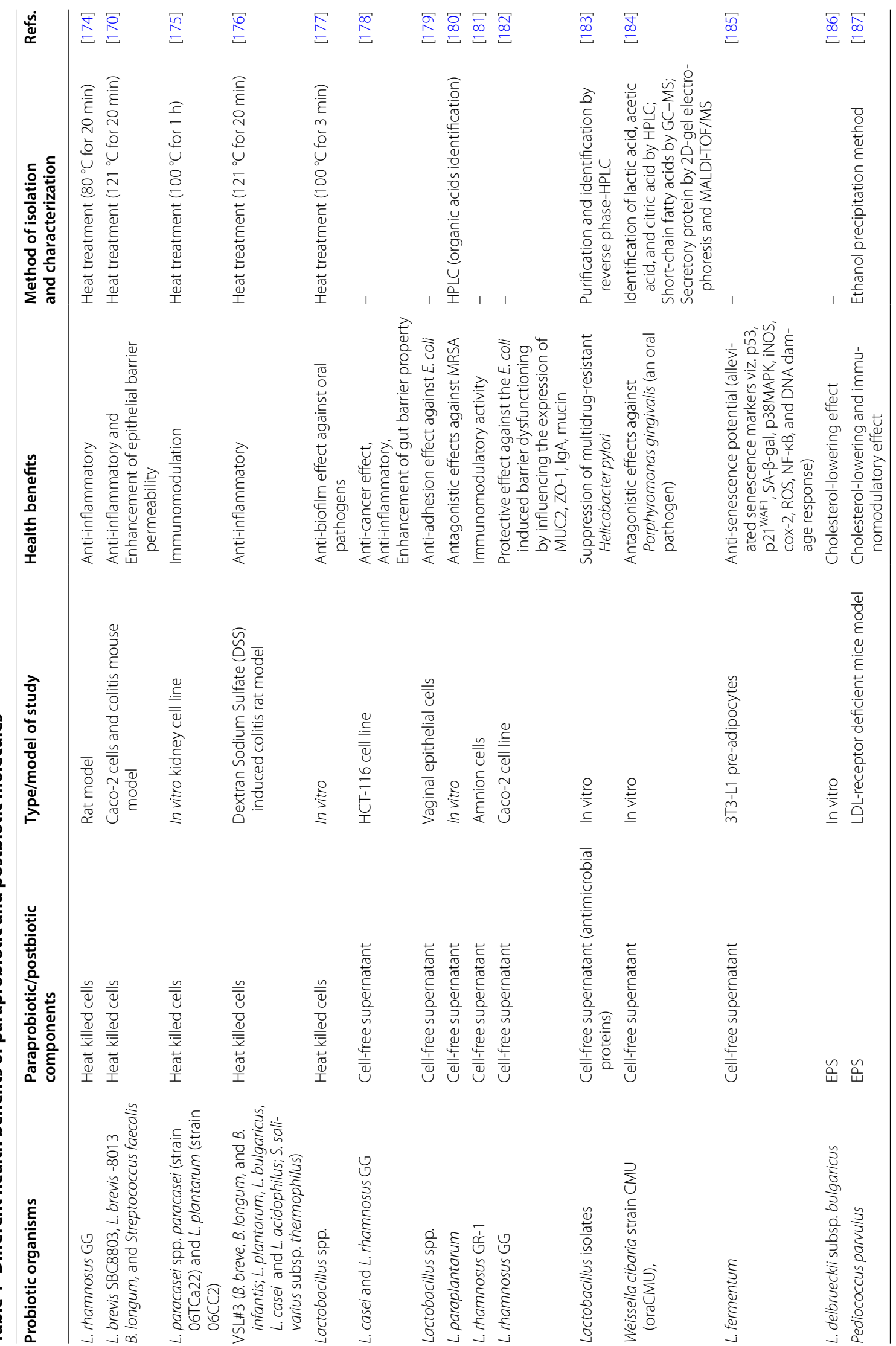




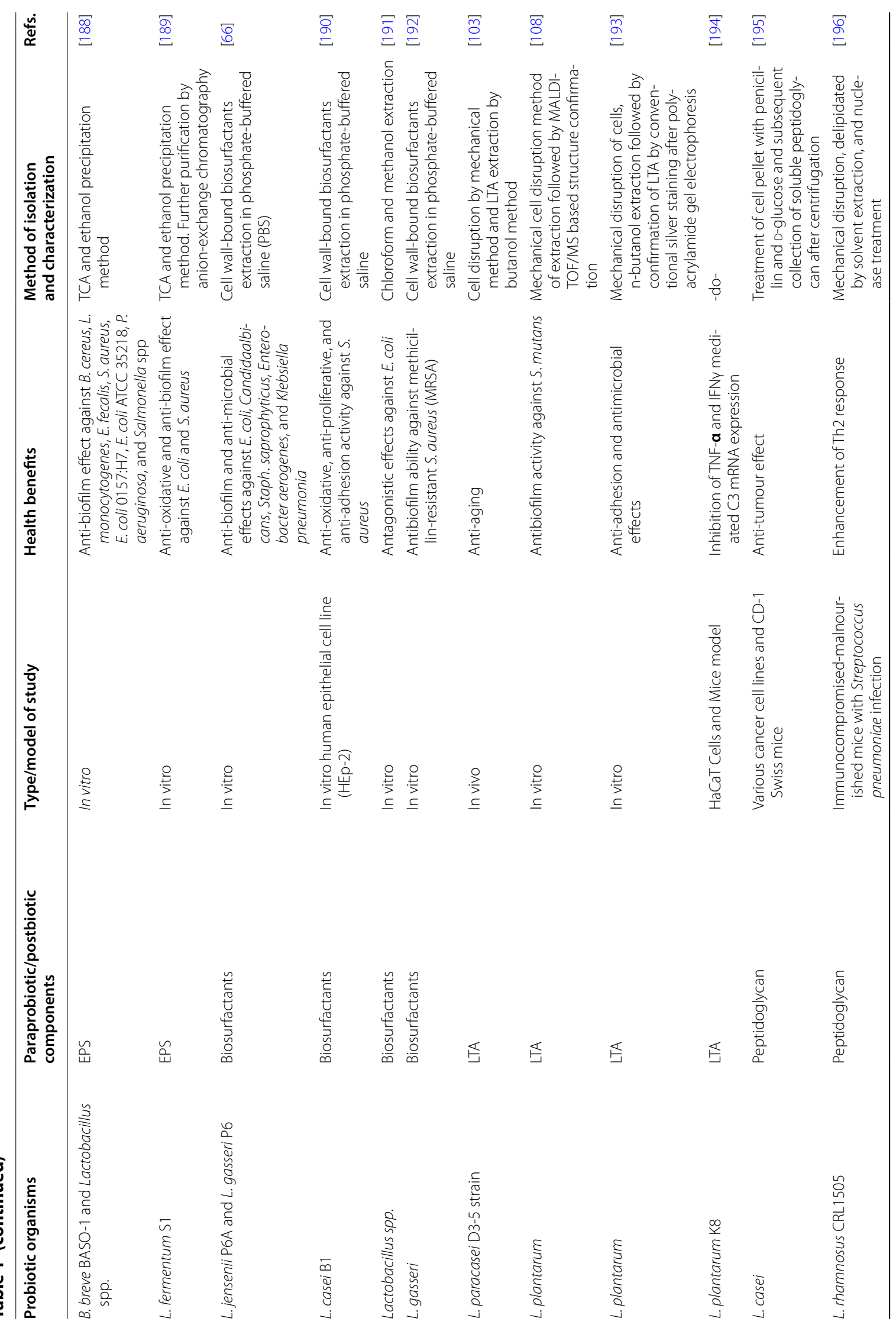




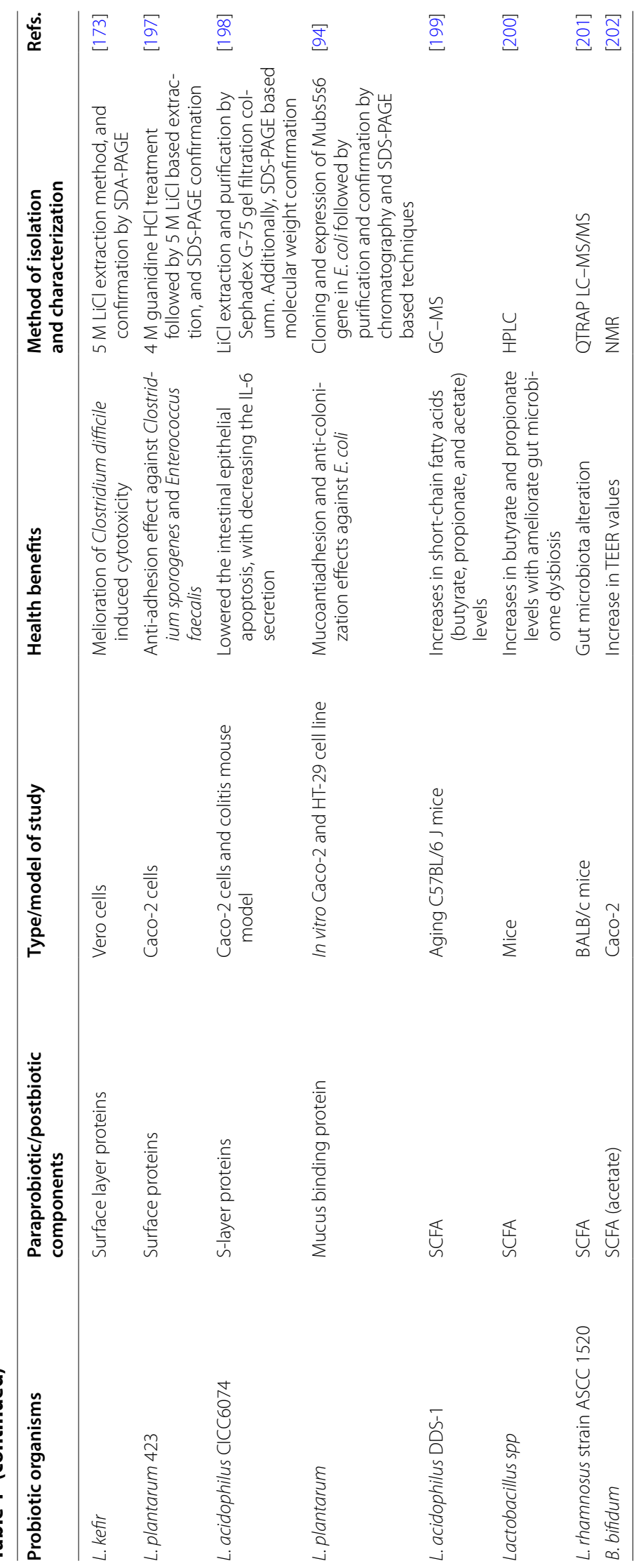


of fermented dairy products since EPS gets hydrated and reduces moisture content [76]. The desired rheology of the products can be achieved either by the EPS production by starter cultures in situ or via the external addition of extracted and purified EPS.

The extraction protocol of EPS includes culturing the EPS producing lactic acid bacteria (LAB) (De Man, Rogosa, and Sharpe/MRS for lactobacilli) in a suitable medium for 12 to $18 \mathrm{~h}$ and subsequent deproteinization of culture supernatant by trichloroacetic acid (TCA) and ethanol precipitation [77]. Since industrial production of EPS cannot relay on the MRS medium, investigators have optimized dairy whey for the sustainable production of EPS from lactic cultures (Fig. 4). On the other hand, purification of extracted EPS can be achieved by chromatography methods, and functional group characterization can be achieved by GC-MS, FTIR spectroscopy, or NMR techniques [78]. The EPS of lactic acid bacteria has also reported exhibiting several biofunctional attributes like anti-oxidative (ability to scavenge wide range of free radicals), cholesterol-lowering (ability to bind free cholesterol) effect, immunomodulatory effect, anti-aging effect, gut microbiota modulation, anti-toxic effect, anti-biofilm effect, and antitumor effects at preclinical trials [78-83].

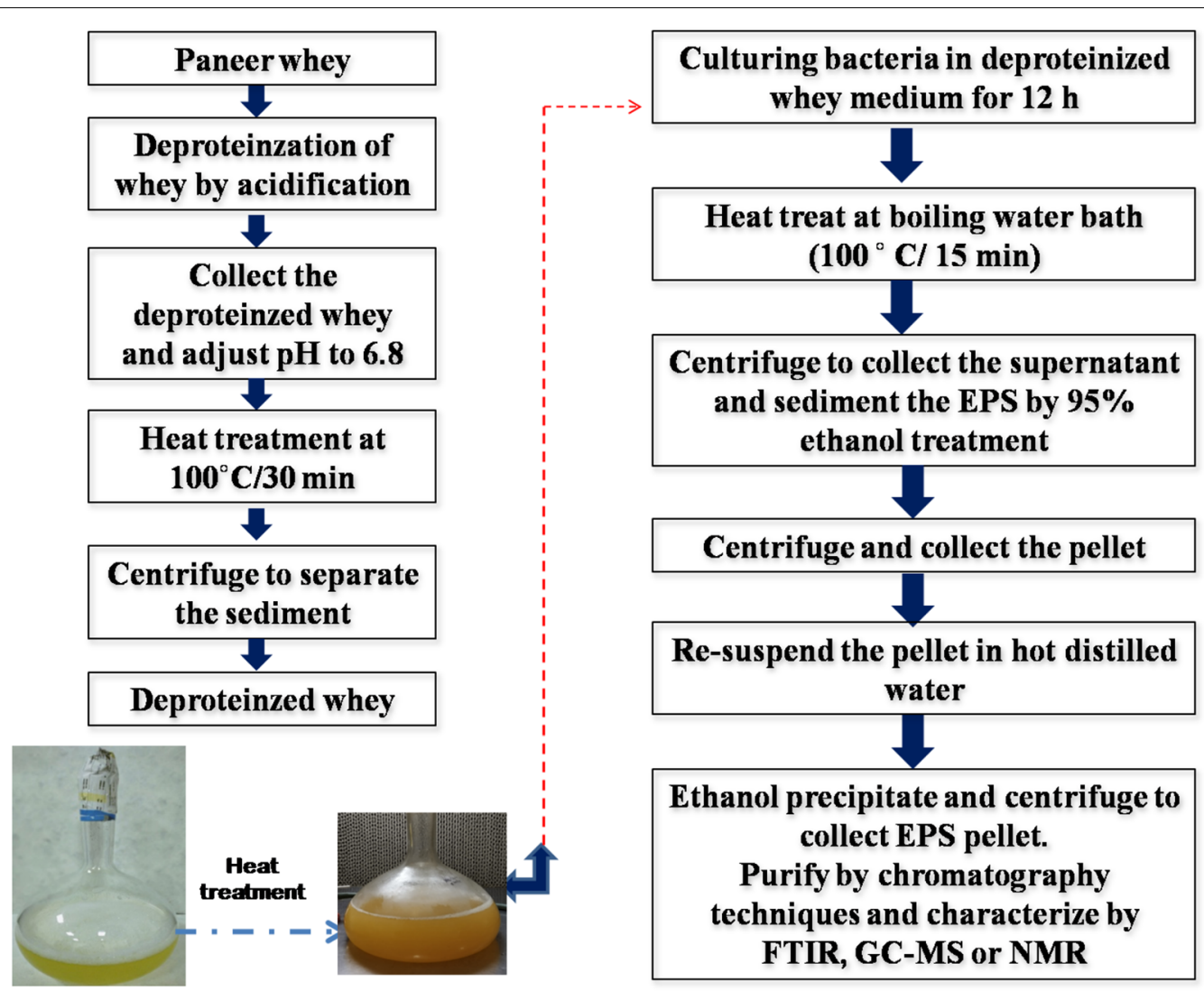

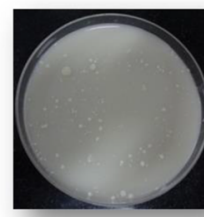

EPS positive

LAB

(Creamy white mucoid colonies)

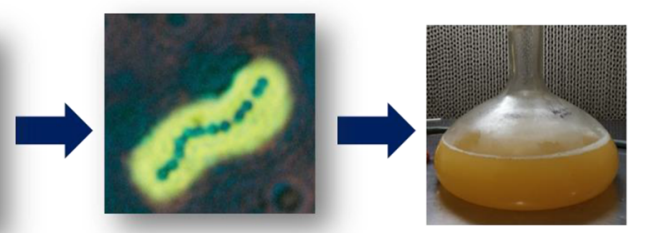

Capsule staining

Whey medium for EPS production

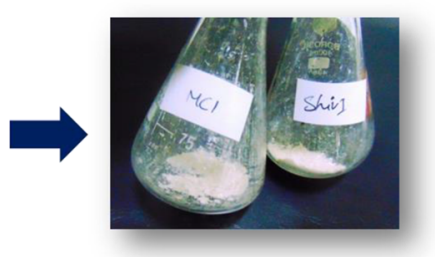

Dried EPS from

LAB as functional ingredient

Fig. 4 An outline on extraction and characterization of EPS from whey-based medium [74] 


\section{Cell surface proteins}

The cell surface proteome of bacterial architecture plays a crucial role in exhibiting the dynamic molecular mechanism of probiotics. The bacterial surface proteins are classified in four categories, which include (i) proteins anchored to the cytoplasmic membrane by hydrophobic transmembrane domains (integral membrane proteins), (ii) lipoproteins (covalently attached to membrane lipids after cleavage of a signal peptide by signal peptidase II), (iii) proteins containing C-terminal LPXTG-like motif and covalently attached to peptidoglycan by sortases, and (iv) non-covalently bound proteins associated with cell wall by weak interactions (van der Waals forces, hydrogen or ion bonds) (LysM proteins, WXL proteins, GW proteins, proteins with choline-binding domains) [84]. The well-characterized cell surface-associated proteins in probiotic bacteria include surface $(S)$ layer protein, mucus binding protein, fibronectin-binding protein, sortase dependent binding protein, collagen-binding protein, and so on (Fig. 5). These surface proteins are vital in probiotic bacterial adhesion to host econiche. Indeed, the probiotic lactobacilli lacking S-layer proteins witnessed the inferior adhesion knack to the gut enterocyte [85]. The cell surface-associated proteins constitute the first-line of contact during the potential interplay with the host which in turn trigger the various cellular process (signal transduction mechanisms) in the intestinal cells involving nuclear factor-kB (NFkB) and mitogenactivated protein kinases (MAPKs). This influences the regulation of downstream pathways such as the secretion of cytokines (chemokines and cytokines) which are responsible for the immunomodulatory action, secretion of antibacterial peptides (defensins), mucin secretion, expression of tight junctions factors, etc. [86-88].

The enzymes (EDTA-lysozyme) and chemical chaotropic agents [lithium chloride, guanidinium hydrochloride, urea, and sodium dodecyl sulphate (SDS)] have been widely reported to shave the surface proteins [84]. The gel-based and non-gel based methods have been widely employed to characterize the extractable proteins (Fig. 6). The gel-based proteomics techniques include separation of surface proteins on Sodium Dodecyl Sulphate-Polyacrylamide Gel Electrophoresis (SDS-PAGE) or two-dimensional (2D) gel electrophoresis and identification of bands by Liquid Chromatography-Mass Spectrometry (LC-MS) (Matrix-Assisted Laser Desorption/ Ionization-Time of flight, MALDI-TOF; or Quad Time of Flight, ESI-Q-TOF) upon tryptic digestion (in gel analysis). However, the gel-free proteome identification constituted the direct digestion of surface proteins with trypsin and analysis of tryptic peptide by LC-MS/MS (short gun proteomics) techniques and followed by bio-informatics analysis [89].

So far, the surface proteins of probiotic bacteria have reported demonstrating anti-inflammatory, anti-adhesion, strengthening the epithelial barrier property, and biosorption of toxic heavy metals [90]. The purified surface proteins of $L$. helveticus significantly hampered the

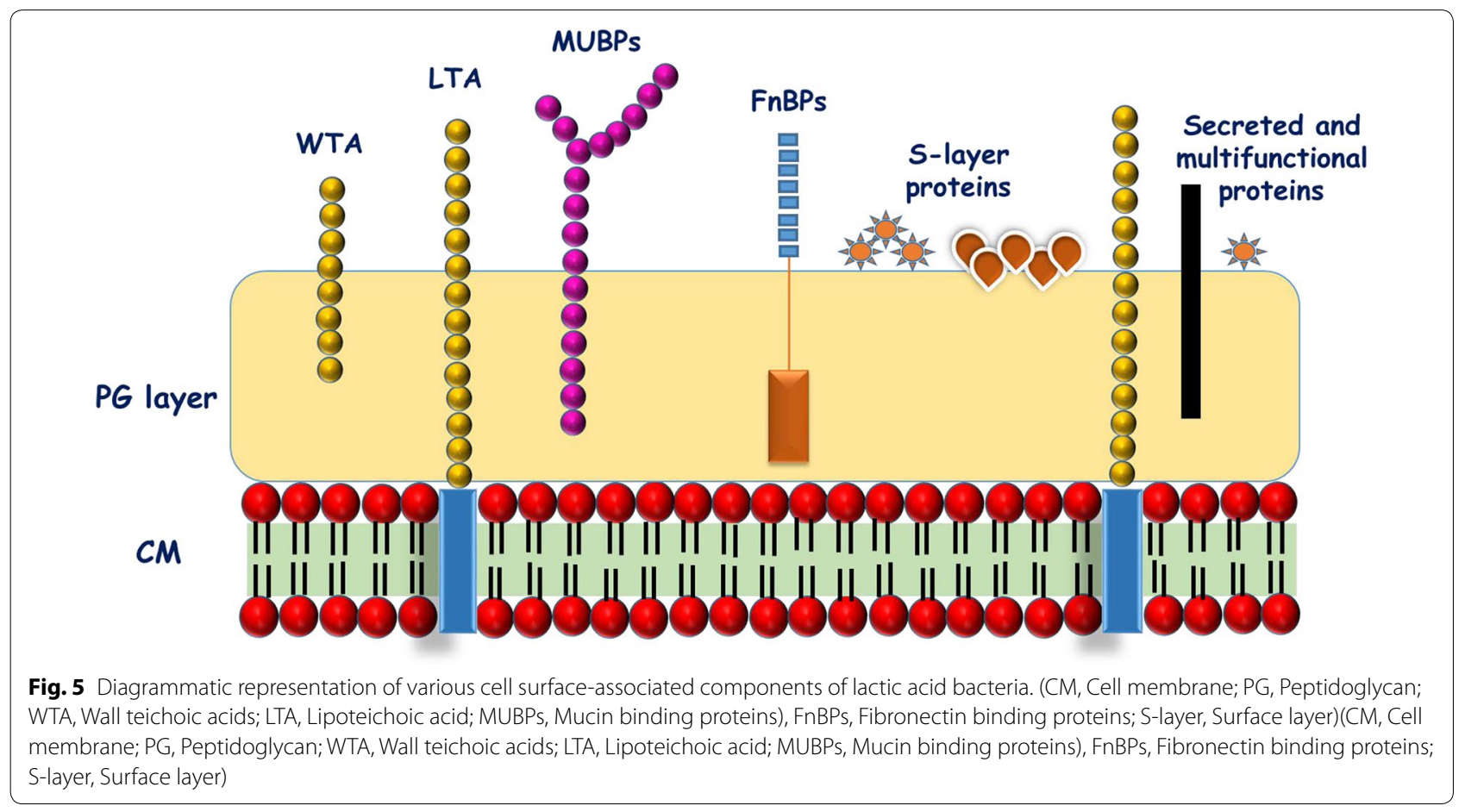




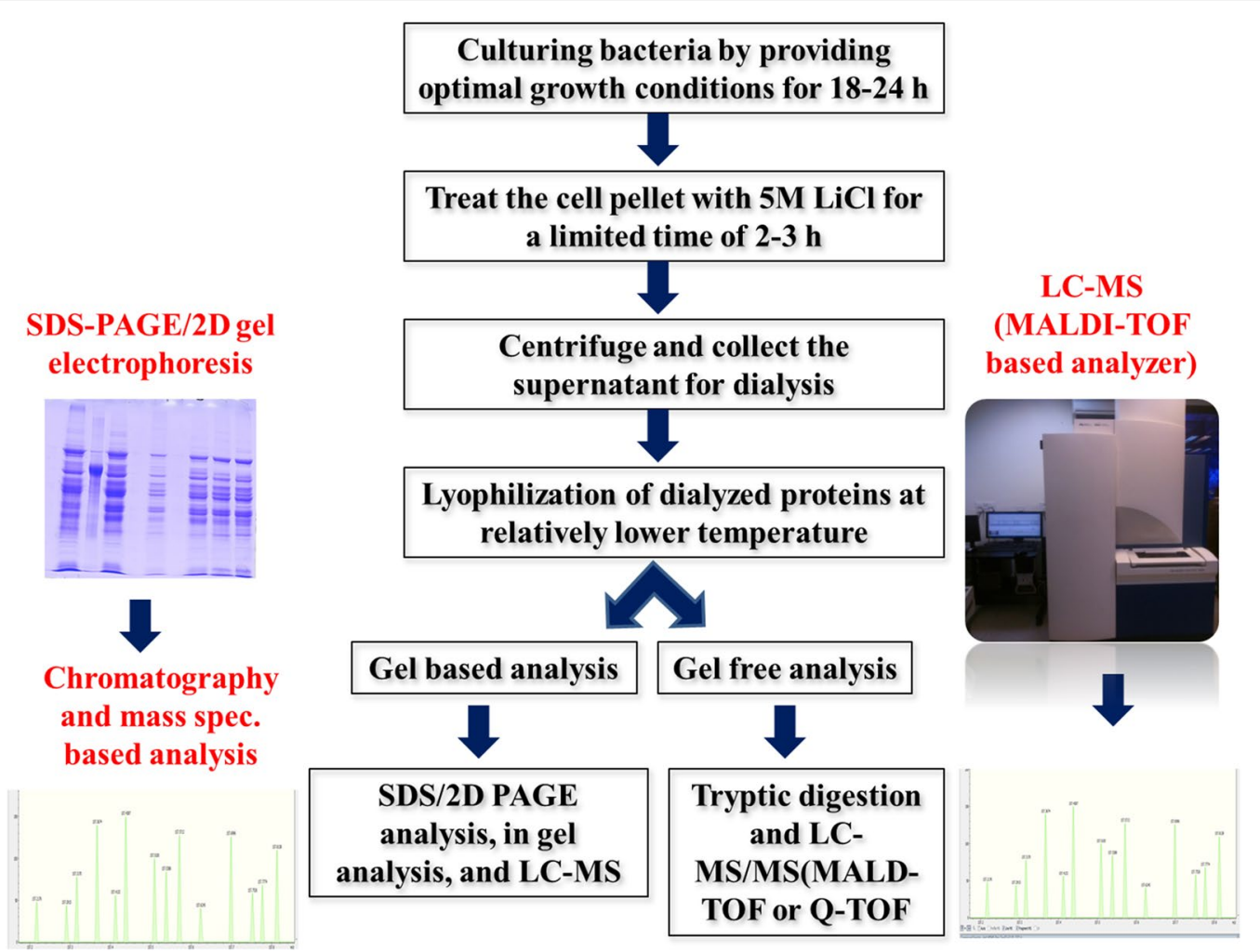

Fig. 6 Brief overview of the extraction and characterization of surface proteins associated with lactobacilli [173]

adhesion of Escherichia coli O157:H7 and enhanced the transepithelial epithelial electrical resistance (TEER) which was initially decreased by E. coli infection in Hep-2 and T84 human epithelial cell lines [91]. In contrast, the extractable surface proteins of $L$. plantarum ameliorated the pathogen invasion by signaling the expression of tight junction proteins viz. Claudin-1, Occludin, JAM-1, and $\mathrm{ZO}-1$, and thus restored the epithelium integrity $[88,92]$. More recently, the extractable surface proteins of (S-layer proteins) of probiotic Enterococcus faecium WEFA23 significantly declined the Listeria monocytogenes induced apoptosis of Caco-2 [93]. Mucus binding proteins (MUB) of $L$. plantarum hampered the adhesion of $E$. coli to the gastric mucin and HT-29 cell line [94]. Apart from pathogen exclusion, the immunomodulation potential of surface proteins is also well documented [95]. The surface proteins of $L$. rhanmosus GG revealed to alleviate the inflammatory cytokines and TLR activation at mRNA level in the in vitro cell line model. Moreover, the surface proteins have attenuated lipopolysaccharides (LPS)induced MAPK and NF-kB signaling pathways activations in the intestinal epithelial cell (IEC) IPEC-J2 [96]. These findings suggest that surface proteins of probiotic bacteria may be the better biotherapeutics in the inflammatory diseases like inflammatory bowel disease (IBD) or colitis.

\section{Teichoic acids}

The surface charge on the peptidoglycan layer of grampositive bacteria is pivoted towards the presence of anionic glycopolymers called wall teichoic acids (WTAs). These play key roles in determining the cell shape, regulation of cell division, and other fundamental metabolic aspects of cell physiology. In addition, teichoic acids also confer pathogenesis and antibiotic resistance to gram-positive bacteria [97-99]. The teichoic acids are chemically the glycopolymers (ribitol) containing phosphodiester-linked polyol repeat units. Teichoic acids are generally of two kinds, which include lipoteichoic acids (LTAs) (anchored in the bacterial membrane via a glycolipid), and wall teichoic acids (WTAs) (covalently attached to peptidoglycan) [100]. The wall teichoic acid polymer can be divided into two components, a disaccharide linkage unit and the main chain polymer composed of phosphodiester-linked polyol repeat units. LTA is an amphiphilic molecule in which the hydrophilic region is made of 1,3-phosphodiester-linked polymer of glycerolphosphate or ribitol-phosphate substituted with D-alanine or sugars. In contrast, the hydrophobic region is a glycolipid (Glc ( $\beta 1-6)$ Glc ( $\beta 1-3)$ diacylglycerol) [101].

The extraction protocol of LTA involves the mechanical disruption of the cell wall of bacteria by sonication in 
the citrate buffer $(0.1 \mathrm{M}, \mathrm{pH}=4)$ to release the teichoic acids from the peptidoglycan layer. The lipophilic cell contaminants from the LTA can be overcome by solvent (n-butanol) extraction. The obtained crude LTA can be purified by gradient hydrophobic chromatography using octylSepharose CL-4B packed in XK 16/60 column with $15 \%$ to $60 \% \mathrm{n}$-propanol in ammonium acetate $(0.1 \mathrm{M}$, $\mathrm{pH}=4.75)$ as mobile phase. To achieve further purity, the collected fractions can be further analyzed for their phosphate content using the phosphomolybdenum test. Nevertheless, the Nuclear Magnetic Resonance (NMR) technique was also employed to study the structural insights of LTA [101].

Ample studies have been conducted to study the functional attributes of LTA, out of which, immunomodulatory potential has much underpinned. LTA is a microbe-associated molecular pattern (MAMP) recognized by pattern recognition receptor (TLR-2) on the surface of gut enterocytes to transduce cellular signals to induce inflammatory cytokines response [102]. On the contrary, the administration of LTA extracted from L. paracasei D3-5 strain to old mice ameliorated the high- fat diet-induced metabolic dysfunctions, decreased leaky gut and inflammation, and improved physical and cognitive functions. Moreover, LTA also stimulated the expression of mucin (Muc2) gene by modulating TLR-2/ p38-MAPK/NF-kB pathway [103]. The LTA from $L$. delbrueckii, L. sakei, and L. rhamnosus GG suppressed the viral double-stranded RNA (poly I:C) induced proinflammatory cytokine (IL-8) in the intestinal epithelial cell line. In contrast, the dealanylated or deacylated LTA did not show the signs of poly I:C-induced IL-8 production, this difference may counsel the role of $\mathrm{D}$-alanine and lipid moieties in contributing functional attributes to LTA structure [104]. In another study, the LTA from the L. rhamnosus GG showed dose-dependent activation of NF- $\kappa$ B signaling in HEK293T (intestinal cell line) and Caco-2 cells after interaction with TLR2/6, but not with TLR2 alone. Besides, the experiments with highly purified LTA of LGG resulted in the IL-8 (pro-inflammatory cytokine) mRNA induction in Caco-2 epithelial cells, whereas the process of dealanylation and deacylation of LTA reduced IL-8 mRNA expression [101]. A study by Ahn et al. demonstrated that LTA extracted from L. plantarum K8 was found to regulate the balance between Th1 and Th2 response (pro and anti-inflammatory response cytokines). The homeostasis was noticed between IL-10 and TNF- $\alpha$ upon treatment to phorbol-12-myristate13-acetate (PMA)-differentiated THP-1 cells (macrophages) with the LTA. Interestingly, this response was found to be highly strain-specific, and the authors failed to observe the same outcomes with LTA of Staphylococcus aureus or L. sake, hence, therapeutic capabilities of LTA can be inferred only after proper examination in suitable models to use LTA [105]. Nevertheless, the cytokine-induced immunomodulatory activity of LTA is further debatable and required a large number of welldesigned experimental models to rule out the specific outcome.

On the other hand, LTA of lactobacilli has been also studied as biofilm disrupting agents. In this connection, the purified LTA extracted from probiotic Lactobacillus strains have demonstrated anti-biofilm actions against oral and enteric pathogens such as Streptococcus mutans, S. aureus, and E. feacalis by preventing the formation of biofilms and disrupting the preformed biofilms [106-108]. Likewise, LTA of L. plantarum could curb the biofilm formation and aggregation without affecting the growth of $S$. aureus in various in vitro and in vivo models [109]. However, it is important to note that the same effect was not observed upon the removal of $\mathrm{D}$-alanine moieties from the LTA structure. Therefore, it is crystal clear that the D-alanine structure in LTA is crucial to provide various functional properties. The in-depth investigation on the mechanism of antibiofilm action of LTA against $S$. aureus demonstrated the control of LTA over ica-operon which is responsible for the production of poly- $\mathrm{N}$-acetylglucosamine (the key molecule in $\mathrm{S}$. aureus biofilm development). Moreover, LTA increased the release of autoinducer-2 from $S$. aureus, which contributes to the inhibition of $S$. aureu biofilm formation. On the other side, LTA treatment enhanced the susceptibility of the biofilm to various antibiotics and macrophages [109].

\section{Peptidoglycan}

The peptidoglycan (PG) sacculus is an indispensable cell wall structural element present most abundantly among Gram-positive bacteria. The peptidoglycan is a linear glycan strand cross-linked by peptides. The peptidoglycan strands are constructed by bonding $\mathrm{N}$-acetylglucosamine (GlcNAc) and N-acetylmuramic acid (MurNAc) residues via beta 1-4 linkages. The peptide chains are linked covalently through their $\mathrm{N}$-terminus to the lactyl group of MurNAc [110]. In contrast, the peptidoglycan structure in $\mathrm{LAB}$ is quite peculiar; the amino acid sequence of the stem peptide is L-Ala-g-D-Glu-y-D-Ala, while the third amino acid (y) is a di-amino acid. In some cases, it is often L-Lys (e.g., in Lactococcus lactis and most lactobacilli) but can also be mesodiaminopimelic acid (mDAP) (e.g., in L. plantarum) or L-ornithine (e.g., in $L$. fermentum). D-Lac, however, replaces D-Ala present at the position fifth position in the newly synthesized PG in a few LAB such as L. casei, L. plantarum, and Leuconostoc spp. that provide innate resistance to vancomycin [111]. Peptidoglycan extraction from probiotic 
lactobacilli is a multistep process that includes both mechanical and enzymatic separation. The obtained cell wall has to be delipidated by the successive solvent extraction method (methanol-chloroform (1:1)). Consequently, delipidated crude preparations should be enzymatically purified by treating with a cocktail of proteases and nucleases [112, 113]. Further, amino acids can be confirmed by SDS-PAGE and carbohydrates can be profiled by chromatographic or NMR techniques. The peptidoglycan extracted from probiotic bacteria demonstrated in vitro and in vivo anti-cancer effect [114, 115], in vivo immunomodulatory activity (peptidoglycan from L. rhamnosus CRL1505 significantly improved lung $\mathrm{CD}^{+}{ }^{+} \mathrm{CD} 4{ }^{+} \mathrm{IFN}-\gamma^{+}$, and $\mathrm{CD} 3{ }^{+} \mathrm{CD} 4{ }^{+} \mathrm{IL}-10^{+} \mathrm{T}$ cells as well as $\mathrm{CD}_{11 \mathrm{c}^{+}}$SiglecF ${ }^{+}$IFN- $\beta^{+}$alveolar macrophages with the consequent increases of IFN- $\gamma$, IL-10, and IFN- $\beta$ in the respiratory tract) $[112,116]$, in vivo anti-inflammatory effect in a colitis mouse model [117]. To date, only the immunomodulatory and anti-proliferative or antitumour effects of probiotics mediated peptidoglycan have explored yet.

\section{Cell-free supernatant and soluble factors}

A unique compositional profile of lactic acid bacteria (LAB) derived cell-free supernatant (CFS) is driving the critical interest among researchers looking at various biomolecules targeting to seek health-promoting properties. CFS of LAB is a consortium of low molecular weight (i.e. hydrogen peroxide, reuterin, organic acids, carbon dioxide, and di-acetylene) and high molecular weight (i.e. bacteriocins and bacteriocins-like substances) compounds which are generally known as metabolites [118-120]. However, the composition of postbiotic metabolites was found to be affected by individual nutrients in the growth medium [121]. The separation of CFS is a lucid technique (Fig. 2) that involves centrifugation $(10,000 \times g$ for $\left.10 \mathrm{~min} @ 4{ }^{\circ} \mathrm{C}\right)$ and membrane filtration $(0.22 \mu \mathrm{m}$ polyethersulfone membrane) of $24 \mathrm{~h}$ grown culture medium [122, 123]. However, the lyophilization or freeze-drying of sterile CFS remains the optional step [124].

The characterization of CFS of $L$. salivarius, $L$. casei 431 , and $L$. acidophilus LA5 resulted in various metabolic byproducts like short-chain fatty acids, organic acids, hydrocarbons, phenol, amino acids, benzoic acids, alcohol, sugars, peptides, etc. [124]. The CFS of the aforementioned probiotic strains revealed anti-microbial and anti-biofilm caliber against Listeria monocytogenus, a zerotolerance pathogen [124]. On the other hand, the other metabolites like phenyllactic acid and lactic acid extracted from L. plantarum CECT-221 revealed inhibitory activity against Carnobacterium piscicola, S. aureus, Pseudomonas aeruginosa, Listeria monocytogenes, and Salmonella enterica. Moreover, the volatiles profiling of CFS of the same probiotic strain revealed natural aromas, such as acetophenone, with a high price in the market [125]. CFS of $L$. rhamnosus GG modulated the mucin expression and antiinflammatory cytokines such as interleukin (IL)-4, IL-5, and IL-10 in HT-29 cell line [126]. Additionally, the CFS of L. acidophilus, L. casei, L. lactis, L. reuteri, and Saccharomyces boulardii appeared to unveil the signs of anti-oxidative knack [127]. More interestingly, the cell-free soluble factors of $E$. coli Nissle 1917 demonstrated the protective effect against enteropathogenic E. coli induced intestinal epithelial barrier dysfunctioning by triggering the expression of tight junction (ZO-1, claudin-14, and claudin-2) gene expression in Caco-2 cellular model [128]. The CFS of the three strains (L. rhamnosus strains SHA111, SHA112, and SHA113 isolated from human breast milk) showed excellent antioxidant activity against DPPH free radicals, superoxide anion radicals, and hydroxyl radicals) and anticancer activity on cervix cancer cells (HeLa) via cytotoxicity and induction of apoptosis through up-regulation of BAD, BAX, Caspase 3, Caspase 8, Caspase 9, and downregulation of $B C L-2$ genes in HeLa cells [129]. In another study, a soluble protein of $12 \mathrm{kDa}$ in CFS of $L$. acidophilus ATCC 43121 exhibited cholesterol-binding activity and thus indicating the cholesterol-lowering activity of postbiotics [130]. On the other hand, CFS of L. acidophilus, $L$. casei, L. reuteri, and S. boulardii were able to downregulate the expression of PGE-2 and IL-8 in human colon epithelial HT-29 cells. Moreover, probiotic supernatant differently modulate IL- $1 \beta$, IL- 6 , TNF- $\alpha$, and IL-10 production by human macrophages, suggesting a typical anti-inflammatory activity [131].

The biofilms of pathogenic bacteria are one of the significant threats to the medical fraternity. The encased bacteria in the biofilm matrix are resistant to different antimicrobials, and thus biofilm seems to be the foremost aspect of pathogenesis and therapeutic failure. In this aspect, several investigators have focused on exploring CFS as an anti-biofilm agent due to its amphiphilic chemical profile. The CFS extracted from Lactobacillus spp. could able to prohibit the onset of biofilm formation and also able to disrupt the preformed biofilms of Cronobacter sakazakii and L. monocytogenes [132]. Similarly, the $\mathrm{pH}$ neutralized CFS of L. plantarum, L. helveticus, Propionibacterium acidilactici, and E. faecium revealed a substantial reduction in biofilm formation of $S$. aureus CMCC26003 and E. coli CVCC230 [133]. To overcome biofilm-forming multi-drug resistant superbugs (P. aeruginosa, S. aureus, and E. coli), investigators have used CFS of LAB for the successful mitigation of pathological conditions [134, 135]. Therefore, these findings suggested that the CFS of LAB may act as bio-liquid-detergent that reduces the adhesion and biofilm formation of pathogens to the various surfaces (biotic and abiotic surfaces). 


\section{Bacteriocins}

Lactic acid bacteria (LAB) produce an array of extracellular antimicrobials that inhibit both pathogenic and spoilage causing microorganisms. In situ production of antimicrobials by protective lactic cultures made their food exploitations more compatible [136]. Although a wide range of microorganisms produces bacteriocins, those produced by LAB have attracted to a greater extent due to their extensive applications in food processing and food fermentations as natural bio-preservatives. For instance, they have been extensively used in the preservation of ample food products like cheese, paneer, meat, and vegetables [137]. Since the bacteriocins are secreted extracellularly, the CFS is used for isolation and purification of proteinous bacteriocins. Briefly, the proteinaceous CFS is precipitated with ammonium sulphate (60-80\%), antagonism can be assayed by native PAGE and peptide sequence is identified by LC-MS/MS [138].

Bacteriocins are ribosomally synthesized antimicrobial peptides produced by both Gram-positive bacteria and Gram-negative bacteria that inhibit closely related species. Few authors classify bacteriocins into two broad categories viz; Class I bacteriocins that are RiPPs (Ribosomally Produced and Post-translationally modified Peptides) having unusual amino acids like lanthionine and $\beta$-methyl lanthionine; Class II that do not contain unusual modifications [139]. On the contrary, there have been several reports classifies the five different classes of bacteriocins. Class I: RiPPs (lantibiotics) having unusual amino acids, Class II: Unmodified bacteriocins (small heat-stable with less than $10 \mathrm{kDa}$ ), Class III: These are unmodified and larger than $30 \mathrm{kDa}$, Class IV: complex bacteriocins having lipid or carbohydrate moieties, Class V: circular bacteriocins [140, 141]. The bacteriocins produced by LAB are generally cationic peptides, which act on cytoplasmic membranes by forming pores [142]. This triggers the leakage of intracellular vital components. However, mechanism of action of lantibiotic (Class A) nisin and pediocin-like bacteriocins is on lipid-bound cell wall precursor lipid II as a docking molecule for subsequent inhibition of peptidoglycan layer. Nisin (US Food and Drug Agency approved bacteriocin) produced by L. lactis subsp. lactis marketed as Nisaplin by Danisco has found to have inhibitory actions against foodborne enteropathogens including Clostridium difficile [143, 144]. Similarly, MicroGARD is another FDA approved commercial preparations by Danisco (skim milk fermentate of Propionibacterium freudenreichii subsp. Shermanii) used as an eminent biopreservative in various dairy and food matrices [145]. Bacteriocins of LAB not only have their potential applications in food preservations but also in the clinical sector as they revealed the inhibitory potential against various urogenital and antibiotic-resistant pathogens [146, 147].

\section{Short chain fatty acids}

The dietary carbohydrate in the food gets digested by the action of various enzymatic actions and absorbed in the intestine. The food contains not only digestible carbohydrates but also the non-digestible fibers which have got a crucial role to play in human health and nutrition such as providing bulkiness to food, assisting the smooth passage of food in GIT, prebiotics action, and so on. Prebiotics are defined as substrates that are selectively utilized by host microorganisms conferring a health benefit [148]. These non-digestible carbohydrates (prebiotics) are selectively get fermented by commensals and probiotic bacteria in the gut to produces various end products such as carbondi-oxide, hydrogen, methane, and short-chain fatty acids (SCFAs), primarily acetate, propionate, and butyrate. Lactobacilli synthesize SCFAs from (i) fermentation of carbohydrates to produce as pyruvate by glycolytic pathway (ii) phosphoketolase pathway for heterofermentative bacteria. However, bifidobacteria use fermentation (Bifidus) pathway to produce majorly the acetate and formate under carbohydrates limited condition, whereas, the acetate and lactate during the existence of carbohydrates in excess. The metabolic fate of acetate is that it enters the peripheral circulation and later metabolized by muscles and other tissues, while the liver takes up leftover propionate [149]. By contrast, the butyrate acts as the primary energy source (70\% of their energy) of colonocytes (monocarboxylate transporter-1 pathway) and also regulates the colonic microbiome, cellular apoptosis, proliferation, and differentiation of the gut enterocytes [150]. It was earlier investigated that the lower concentrations $(<0.5 \mathrm{mM})$ of butyrate acts as the energy source to the cells (constructive manner), however, in contrast, higher concentrations of butyrate $(0.5-5 \mathrm{mM})$ was found to inhibit histone deacetylase (HDACi) and arrest the cell cycle with apoptosis by p53-dependent and -independent manner (destructive manner) [151]. Although few studies indicate probiotic LAB does not primarily produce butyrate [152], there have been sufficient findings that showcases the supplementation of probiotics cocktail has significantly enhanced the propionate and butyrate by modulating the gut microbiota [153]. For example, the consortium of acetate, propionate, and butyrate was found effective against the growth of gastro-intestinal pathogens like Clostridium difficile (involved in antibiotic-associated diarrhea) and E. coli [154]. The extraction and identification of SCFAs rely on solvent extraction and HPLC techniques. Nevertheless, the use of GC-MS is more analytical rather preparative. However, GC-MS provides overall insights on fatty acids in the mixture $[153,155]$.

In recent days, there has been increasing evidence on the therapeutic approaches of short-chain fatty acids in 
the management of IBD and colorectal cancer due to their potentiality to overcome the inflammation and proliferation of cancerous cells respectively [156]. The findings of a randomized clinical trial by Cremon et al. indicate a considerable increase in the SCFAs viz. acetate and butyrate and reduction in the pro-inflammatory cytokine IL-15 upon supplementation of $L$. paracasei CNCM I-1572 to the irritable bowel syndrome (IBS) patients [157]. Additionally, SCFAs modulate the Caco-2 trans permeability by enhancing TEER values and tight junction proteins genes expression [158-162], thus suggested the possible influence of SCFAs in modulating the intestinal barrier property and may be relevant for segmented or targeted consumers of different phases of life.

\section{Vitamins}

Vitamins are the organic molecules that are supplemented in the diet in a small amount to facilitate various biological processes in the body. Most B-complex group vitamins are directly involved as coenzymes in several energy metabolism reactions [162]. In contrast, Vitamin $\mathrm{K}$ is the only fat-soluble vitamin that acts as a coenzyme. Humans are incapable of biosynthesizing most of the vitamins, and therefore they subsequently have to be supplemented exogenously. Most of the vitamins have to be supplemented through the diet (vitamin A, D, E, etc.), however, limited vitamins (folic acid-B9, cobalamin-B12, Riboflavin-B2) are even synthesized by commensal gut bacteria and some probiotic bacteria [163]. Although most of the vitamins exist in natural food systems, vitamin deficiency is still a significant challenge for the medical fraternity, majorly due to the malnutrition, unbalanced diets, and altered food habits. B-group vitamins, normally present in many foods, are easily destroyed during the thermal processing of foods. For this reason, the fortification of certain foods with specific vitamins is necessary. In contrast, the dietary intervention of various in situ vitamins producing LAB (Table 2) is also a benign approach to overcome such deficiency. The use of such microorganisms is also an economically viable alternative than fortification with chemically synthesized pseudo-vitamins. This indeed allows the production of foods with enhanced levels of vitamins that are rare to cause side effects. Cobalamin is most preferably produced by industrial microbial fermentation, as chemical synthesis is very costly. However, cheap agrobyproducts are most preferable as a raw material for such fermentations. In this connection, Deptula et al. utilized a whey-based liquid medium for the production of vitamin B12 from Propionibacterium freudenreichii 2067 [164]. The identification of biosynthesized vitamins from natural or over-expressed LAB strains can assess by spectrophotometrically and chromatographic (HPLC) techniques depending on the type of vitamins $[164,165]$.

The genome annotation of 256 human gut bacteria revealed the enzymes for biosynthesis pathways for eight B-vitamins (biotin, cobalamin, folate, niacin, pantothenate, pyridoxine, riboflavin, and thiamin) [166]. Amongst $\mathrm{LAB}$, lactococci and Lactobacillus (brevis, fermentum, reuteri, salivarius) displayed the complete genes (ribA, ribB, ribG, and ribH) for riboflavin synthesis $[167,168]$. In a clinical trial, the supplementation of probiotic strain B. animalis subsp. lactis HNO19 (DR10 ${ }^{\mathrm{TM}}$ ) among pregnant women resulted in a significant increase in vitamin

Table 2 Vitamins and short chain fatty acids producing LAB and other adjunct cultures

\begin{tabular}{|c|c|c|}
\hline Organisms & Components & References \\
\hline $\begin{array}{l}\text { Streptococcus gallolyticus subsp. macedonicus (S. macedonicus) } \\
\text { CRL415 }\end{array}$ & Folate & {$[203]$} \\
\hline Propionibacterium freudenreichii DSM 20271 & Vitamin B12 & {$[204]$} \\
\hline E. faecalis, L. helveticus, and L. acidophilus & Formic acid, acetic acid, vitamin B1 & {$[205]$} \\
\hline L. brevis, L. plantarum, and L.pentosus & Acetic, propionic butyric, isobutyric isovaleric & {$[206]$} \\
\hline Propionibacterium freudenreichii & Vitamin B12 & {$[207]$} \\
\hline L. pentosus var. plantarum BFP32 & Acetic, butyric, and propionic acid & {$[208]$} \\
\hline L. pentosus var. plantarum BFP32 & Vitamins B1 and B2 & {$[208]$} \\
\hline Lactobacillus spp. & Vitamin B12 & {$[209]$} \\
\hline L. sakei, L. plantarum & Folate & {$[210]$} \\
\hline L. plantarum and L. coryniformis & Vitamin B12 & {$[210]$} \\
\hline $\begin{array}{l}\text { L. delbrueckii subsp. bulgaricus CRL 863, S. thermophilus CRL 415, and } \\
\text { CRL } 803\end{array}$ & Folate & {$[203]$} \\
\hline Propionibacterium freudenreichii DF15 & Vitamin B12 & {$[211]$} \\
\hline L. plantarum, L. reuteri, L. brevis, and L. fermentum & Folate & {$[211]$} \\
\hline B. breve M-16V & Acetate & {$[212]$} \\
\hline
\end{tabular}


B6 in the blood concentration and vitamin B12 in the second and third trimester [169]. Such evidence suggests the significance of fermented products in overcoming micronutrients (vitamins) deficiency.

\section{Concluding remarks}

To summarize, 'paraprobiotics' (dead/inactive cells of probiotics) and 'postbiotics' (healthful metabolites of probiotics) are the evolving concepts in the functional biotics arena. These have several advantages over the traditional probiotics like known molecular structure, use in purified forms, the specific mechanism of action, better accessibility of MAMP-PRR interaction in triggering a specific downstream pathway, better availability of production process for industrial scale-up, ease in production and storage, etc. The various beneficial properties of parprobiotics and postbiotics include antiinflammatory, gut barrier property, anti-adhesion, anti-biofilm, antiviral, immunomodulatory, antihypertensive, hypocholesterolemic, anti-proliferative, antioxidant, etc. attributes have documented yet. These attributes suggest the potentiality of paraprobiotic and postbiotic molecules to enhance the host health by modulating the host physiology (ameliorating the disease condition or preventing the onset of disease condition). But, there is a high need for human/clinical trials focusing on the validation of health claims of these bioactive molecules. The trials in immunocompromised subjects would be further augmentable to investigate the tolerance of immunocompromised subjects on these biomolecules. On the other hand, we do lack of knowledge about the stability of paraprobiotics and postbiotics under in vitro and in vivo digestive conditions to comprehend specific mechanistic actions by interacting with the ligands.

\section{Authors' contributions}

$\mathrm{BHN}$ and SAA wrote the manuscript and designed figures. PVB and HY contributed to the final correction of manuscript. All authors read and approved the final manuscript.

\footnotetext{
Funding

Authors are thankful for the support provided by the ICAR- National Dairy Research Institute (BHN, SAA, and PVB) and by the National Institutes of Health grants- R01AG018915 and the Pepper Older Americans for Independence Center (P30AG21332), and the Department of Defense funding W81XWH-19-1-0236 (HY), as well funds and services provided from the Center for Diabetes, Obesity and Metabolism, Wake Forest Baptist Medical Center, and the National Center for Advancing Translational Sciences (NCATS), the National Institutes of Health-funded Wake Forest Clinical and Translational Science Institute (WF CTSI) through Grant Award Number UL1TR001420 (HY). It is to declare here that no intellectual property, financial interests and exchanges took place for this work between authors and institutes. There was no role of the funding bodies in the design of the study and collection, analysis, and interpretation of data.
}

\section{Competing interest}

Dr. Yadav is Cheif Scientific Officer and Cofounder of the Postbiotics Inc, however, there is competing and conflict of interest exist between Postbiotics Inc and any authors for current manuscript.

\section{Author details}

${ }^{1}$ Technofunctional Starters Lab, National Collection of Dairy Cultures (NCDC), Dairy Microbiology Division, ICAR-National Dairy Research Institute, Karnal, Haryana 132001, India. ${ }^{2}$ Proteomics and Cell Biology Lab, Animal Biotechnology Center, ICAR-National Dairy Research Institute, Karnal, Haryana 132001, India. ${ }^{3}$ Department of Internal Medicine-Molecular Medicine and Microbiology and Immunology, Wake Forest School of Medicine, Biotech Place, Room 2E-034, 575 North Patterson Ave, Winston-Salem, NC 27101, USA.

Received: 3 June 2020 Accepted: 13 August 2020

Published online: 20 August 2020

\section{References}

1. Sánchez B, Delgado S, Blanco-Míguez A, Lourenço A, Gueimonde M, Margolles A. Probiotics, gut microbiota, and their influence on host health and disease. Mol Nutr Food Res. 2017;6:1600240.

2. Gul K, Singh AK, Jabeen R. Nutraceuticals and functional foods: the foods for the future world. Crit Rev Food Sci. 2016;56:2617-27.

3. Bhat MI, Kumari A, Kapila S, Kapila R. Probiotic lactobacilli mediated changes in global epigenetic signatures of human intestinal epithelial cells during Escherichia coli challenge. Ann Microbiol. 2019;69:603-12.

4. Ghadimi D, Helwig U, Schrezenmeir J, Heller KJ, de Vrese M. Epigenetic imprinting by commensal probiotics inhibits the IL-23/IL-17 axis in an in vitro model of the intestinal mucosal immune system. J Leukocyte Biol. 2012;92:895-911.

5. Lorenzo JM, Munekata PE, Gómez B, Barba FJ, Mora L, Pérez-Santaescolástica C, Toldrá F. Bioactive peptides as natural antioxidants in food products-a review. Trends Food Sci Technol. 2018;79:136-47.

6. Fernandes SS, Coelho MS, de las Mellado MM. Bioactive compounds as ingredients of functional foods: polyphenols, carotenoids, peptides from animal and plant sources new. In: Maira RSC, editor. Bioactive compound. Cambridge: Woodhead Publishing-Elsevier; 2019. p. 129-42.

7. Konar N, Toker OS, Palabiyik I, Polat DG. Importance of chocolates in functional foods: formulation, production process, and potential health benefits. In: Verma DK, Patel AR, Srivasta PP, editors. Bioprocessing technology in food and health: Potential applications and emerging scope. New Jersey: Apple Academic Press; 2018. p. 23-64.

8. Martirosyan DM, Singh J. A new definition of functional food by FFC: what makes a new definition unique? Funct Food Health Dis. 2015;5:209-23.

9. Aguiar LM, Geraldi MV, Cazarin CBB, Junior MRM. Functional food consumption and its physiological effects. In: Maira RSC, editor. Bioactive compound. Cambridge: Woodhead Publishing-Elsevier; 2019. p. 205-25.

10. Baruah R, Kumar K, Goya A. Functional foods and their health benefits In: Saran S, Babu V, Chaubey A, editors. High value fermentation products: human Welfare. New Jersey: Scrivener publishing-Wiley; 2019. p. 127-45.

11. Bagchi D. Nutraceutical and functional food regulations in the United States and around the world. 3rd ed. Cambridge: Academic PressElsevier; 2019.

12. Gore FM, Bloem PJ, Patton GC, Ferguson J, Joseph V, Coffey C, Sawyer SM, Mathers CD. Global burden of disease in young people aged 10-24 years: a systematic analysis. Lancet. 2011;377:2093-102.

13. Daneman D. Update on medical management of diabetes in children and adolescents: epidemiology and treatment. In: Delamater AM, Marrero DG, editors. Behavioral diabetes. New Yor: Springer; 2020. p. 7-16.

14. Abrignani MG, Luca F, Favilli S, Benvenuto M, Rao CM, Di Fusco SA, Gabrielli D, Gulizia MM. Lifestyles and cardiovascular prevention in childhood and adolescence. Pediatr Cardiol. 2019;40:1113-25.

15. Ali A, Rahut DB. Healthy foods as proxy for functional foods: consumers' awareness, perception, and demand for natural functional foods in Pakistan. Int J Food Sci Tech. 2019;2019:1-13. 
16. Hill C, Guarner F, Reid G, Gibson GR, Merenstein DJ, Pot B, Morelli L, Canani RB, Flint HJ, Salminen S, Calder PC. The international Scientific Association for Probiotics and Prebiotics consensus statement on the scope and appropriate use of the term probiotic. Nat Rev Gastroenterol Hepatol. 2014;11:506-14.

17. O'Toole PW, Marchesi JR, Hill C. Next-generation probiotics: the spectrum from probiotics to live biotherapeutics. Nat microbial. 2017;2:1-6.

18. Basavaprabhu HN, Sonu KS, Prabha R. Mechanistic insights into the action of probiotics against bacterial vaginosis and its mediated preterm birth: an overview. Microb Pathogenesis. 2020;141:104029.

19. Kisan BS, Kumar R, Ashok SP, Sangita G. Probiotic foods for human health: a review. J Pharmacogn Phytochem. 2019;8:967-71.

20. Majeed M, Nagabhushanam K, Arumugam S, Majeed S, Ali F. Bacillus coagulans MTCC 5856 for the management of major depression with irritable bowel syndrome: a randomised, double-blind, placebo controlled, multi-centre, pilot clinical study. Food Nutr Res. 2018:62:1218.

21. Suez J, Zmora N, Segal E, Elinav E. The pros, cons, and many unknowns of probiotics. Nat Med. 2019;25:716-29.

22. Ayichew T, Belete A, Alebachew T, Tsehaye H, Berhanu H, Minwuyelet A. Bacterial probiotics their importances and limitations: a review. J Nutr Health Sci. 2017:4:202.

23. Evivie SE, Huo GC, Igene JO, Bian X. Some current applications, limitations and future perspectives of lactic acid bacteria as probiotics. Food Nutr. Res. 2017;61:1318034.

24. Shenderov BA. Metabiotics: novel idea or natural development of probiotic conception. Microb Ecol Health Dis. 2013;24:20399.

25. Reid G, Younes JA, Van der Mei HC, Gloor GB, Knight R, Busscher HJ. Microbiota restoration: natural and supplemented recovery of human microbial communities. Nat Rev Microb. 2011;9:27-38.

26. Baugher JL, Klaenhammer TR. Application of omics tools to understanding probiotic functionality. J Dairy Sci. 2011:94:4753-65.

27. Bron PA, Grangette C, Mercenier A, de Vos WM, Kleerebezem M Identification of Lactobacillus plantarum genes that are induced in the gastrointestinal tract of mice. J Bacteriol. 2004;186:5721-9.

28. Sharma M, Shukla G. Metabiotics: one step ahead of probiotics; an insight into mechanisms involved in anticancerous effect in colorectal cancer. Front Microbiol. 2016;7:1940

29. Malashree L, Angadi V, Yadav KS, Prabha R. Postbiotics. One step ahead of probiotics. Int J Curr Microbiol Appl Sci. 2019;8:2049-53.

30. Aguilar-Toalá JE, Garcia-Varela R, Garcia HS, Mata-Haro V, GonzálezCórdova AF, Vallejo-Cordoba B, Hernández-Mendoza A. Postbiotics: an evolving term within the functional foods field. Trends Food Sci Technol. 2018;75:105-14.

31. Langella P, Martín R. Emerging health concepts in the probiotics field: streamlining the definitions. Front Microbiol. 2019;10:1047.

32. Taverniti V, Guglielmetti S. The immunomodulatory properties of probiotic microorganisms beyond their viability (ghost probiotics: proposal of paraprobiotic concept). Genes Nutr. 2011;6:261.

33. Zendeboodi F, Khorshidian N, Mortazavian AM, da Cruz AG. Probiotic: conceptualization from a new approach. Curr Opin Food Sci. 2020. https://doi.org/10.1016/j.cofs.2020.03.009.

34. Tsilingiri K, Barbosa T, Penna G, Caprioli F, Sonzogni A, Viale G, Rescigno M. Probiotic and postbiotic activity in health and disease: comparison on a novel polarised ex vivo organ culture model. Gut. 2012;2012(61):1007-15.

35. Jang HJ, Song MW, Lee NK, Paik HD. Antioxidant effects of live and heatkilled probiotic Lactobacillus plantarum Ln1 isolated from kimchi. Int J Food Sci Tech. 2018:55:3174-80.

36. Hsieh FC, Lan CCE, Huang TY, Chen KW, Chai CY, Chen WT, Fang AH, Chen YH, Wu CS. Heat-killed and live Lactobacillus reuteri GMNL-263 exhibit similar effects on improving metabolic functions in high-fat diet-induced obese rats. Food Funct. 2016;7:2374-88.

37. Thakur BK, Saha P, Banik G, Saha DR, Grover S, Batish VK, Das S. Live and heat-killed probiotic Lactobacillus casei Lbs2 protects from experimental colitis through Toll-like receptor 2-dependent induction of T-regulatory response. Int Immunopharmacol. 2016;36:39-50.

38. Singh TP, Kaur G, Kapila S, Malik RK. Antagonistic activity of Lactobacillus reuteri strains on the adhesion characteristics of selected pathogens. Front Microbiol. 2017;8:486.

39. Piqué N, Berlanga M, Miñana-Galbis D. Health benefits of heat-killed (Tyndallized) probiotics: an overview. Int J Mol Sci. 2019;20:2534.
40. Cavallari JF, Fullerton MD, Duggan BM, Foley KP, Denou E, Smith BK, Desjardins EM, Henriksbo BD, Kim KJ, Tuinema BR, Stearns JC. Muramyl dipeptide-based postbiotics mitigate obesity-induced insulin resistance via IRF4. Cell Metab. 2017;25:1063-74.

41. Cortés-Martín A, Selma MV, Tomás-Barberán FA, González-Sarrías A, Espín JC. Where to look into the puzzle of polyphenols and health? The postbiotics and gut microbiota associated with human metabotypes. Mol Nutr Food Res. 2020;64:1900952.

42. Wang Y, Qin S, Jia J, Huang L, Li F, Jin F, Ren Z, Wang Y. Intestinal microbiota-associated metabolites: crucial factors in the effectiveness of herbal medicines and diet therapies. Front Physiol. 2019;10:1343.

43. Singhal B, Vishwakarma $\vee$, Singh A. Metabiotics: the functional metabolic signatures of probiotics: current state-of-art and future research priorities-metabiotics: probiotics effector molecules. Adv Biosci Biotechnol. 2018;9:720-6.

44. Rescigno M, Penna G. Postbiotic-based composition for treatment of ocular inflammation. U.S. Patent Application 16/322,394. 2019.

45. Mohamadzadeh M, Sahay B, Salek-Ardakani S, Tahiliani V. University of Florida Research Foundation Inc, 2017. Lipoteichoic acid from lactobacilli as a potent immune stimulatory adjuvant for vaccine development. U.S. Patent Application 15/303,760.

46. Foo HL, Loh TC, Chuah LO, Alitheen NB, Rahim RA. Universiti Putra Malaysia (UPM), 2016. Tumour cytotoxic agent and methods thereof. U.S. Patent 9,480,721.

47. Loh TC, Foo HL. Universiti Putra Malaysia (UPM), 2016. Monogastric animal feed. US Patent 9,271,518.

48. Foo HL, Loh TC, Karunakaramoorthy A, Shamsudin MN, Rahim RHA. Universiti Putra Malaysia (UPM), 2013. Metabolites in animal feed. U.S. Patent Application 13/580,337.

49. Deshpande G, Athalye-Jape G, Patole S. Para-probiotics for preterm neonates. Next Front Nutr. 2018;10:E871.

50. Lin WH, Yu B, Lin CK, Hwang WZ, Tsen HY. Immune effect of heat-killed multistrain of Lactobacillus acidophilus against Salmonella typhimurium invasion to mice. J Appl Microbiol. 2007;102:22-31.

51. Toziou PM, Barmpalexis P, Boukouvala P, Verghese S, Nikolakakis I. Quantification of live Lactobacillus acidophilus in mixed populations of live and killed by application of attenuated reflection Fourier Transform Infrared Spectroscopy combined with chemometrics. J Pharmaceut Biomed. 2018;154:16-22.

52. Caimari $A$, del Bas JM, Boqué $N$, Crescenti A, Puiggròs $F$, Chenoll $E$, Martorell P, Ramón D, Genovés S, Arola L. Heat-killed Bifidobacterium animalis subsp. Lactis CECT 8145 increases lean mass and ameliorates metabolic syndrome in cafeteria-fed obese rats. J Funct Foods. 2017;38:251-63.

53. Chung IC, OuYang CN, Yuan SN, Lin HC, Huang KY, Wu PS, Liu CY, Tsai KJ, Loi LK, Chen YJ, Chung AK. Pretreatment with a heat-killed probiotic modulates the NLRP3 inflammasome and attenuates colitis-associated colorectal cancer in mice. Nutrients. 2019;11:516.

54. Hara T, Mihara T, Ishibashi M, Kumagai T, Joh T. Heat-killed Lactobacillus casei subsp. casei 327 promotes colonic serotonin synthesis in mice. J Funct Foods. 2018:47:585-9.

55. Saito H, Nakakita Y, Segawa S, Tsuchiya Y. Oral administration of heatkilled Lactobacillus brevis SBC8803 elevates the ratio of acyl/des-acyl ghrelin in blood and increases short-term food intake. Benef Microbes. 2019;10:671-7.

56. Sugahara H, Yao R, Odamaki T, Xiao JZ. Differences between live and heat-killed bifidobacteria in the regulation of immune function and the intestinal environment. Benef Microbes. 2017:8:463-72.

57. Kaczorek E, Pacholak A, Zdarta A, Smułek W. The impact of biosurfactants on microbial cell properties leading to hydrocarbon bioavailability increase. Colloid Interf. 2018;2:35.

58. Satpute SK, Kulkarni GR, Banpurkar AG, Banat IM, Mone NS, Patil RH, Cameotra SS. Biosurfactant/s from lactobacilli species: properties, challenges and potential biomedical applications. J Basic Microbiol. 2016;56:1140-58.

59. Patowary K, Patowary R, Kalita MC, Deka S. Characterization of biosurfactant produced during degradation of hydrocarbons using crude oil as sole source of carbon. Front Microbial. 2017:8:279.

60. Ahimou F, Paquot $M$, Jacques $P$, Thonart P, Rouxhet PG. Influence of electrical properties on the evaluation of the surface hydrophobicity of Bacillus subtilis. J Microbiol Methods. 2001;45:119-26. 
61. Velraeds MM, van de Belt-Gritter B, Busscher HJ, Reid G, van der Mei $\mathrm{HC}$. Inhibition of uropathogenic biofilm growth on silicone rubber in human urine by lactobacilli-A teleologic approach. World J Urol. 2000;18:422-6.

62. Sharma D, Saharan BS, Kapila S. Applications of biosurfactants. In: Sharma D, Saharan BS, Kapil S, editors. Biosurfactants of lactic acid bacteria. New York: Springer; 2016. p. 73-82.

63. Elshikh M, Marchant R, Banat IM. Biosurfactants: promising bioactive molecules for oral-related health applications. FEMS Microbiol Lett. 2016;363:213.

64. Luong TM, Ponamoreva ON, Nechaeva IA, Petrikov KV, Delegan YA Surin AK, Linklater D, Filonov AE. Characterization of biosurfactants produced by the oil-degrading bacterium Rhodococcus erythropolis S67 at low temperature. World J Microb Biot. 2018;34:2-20.

65. Moldes AB, Torrado AM, Barral MT, Domínguez JM. Evaluation of biosurfactant production from various agricultural residues by Lactobacillus pentosus. J Agr Food Chem. 2007;55:4481-6.

66. Morais IM, Cordeiro AL, Teixeira GS, Domingues VS, Nardi RM, Monteiro AS, Alves RJ, Siqueira EP, Santos VL. Biological and physicochemical properties of biosurfactants produced by Lactobacillus jensenii P $6 \mathrm{~A}$ and Lactobacillus gasseri P 65. Microb Cell Fact. 2017;16:155.

67. Kaur HP, Prasad B, Kaur S. A review on applications of biosurfactants produced from unconventional inexpensive wastes in food and agriculture Industry. World J Pharm Res. 2015;4:827-42.

68. Banat I, Thavasi R. Downstream processing of microbial biosurfactants. In: Thavasi R, Banat l, editors. Microbial biosurfactants and their environmental and industrial applications. Boca Raton: CRC Press; 2018. p. 16.

69. Fracchia L, Banat JJ, Cavallo M, Banat IM. Potential therapeutic applications of microbial surface-active compounds. AIMS Bioeng. 2015;2:144-62.

70. Welman AD, Maddox IS. Exopolysaccharides from lactic acid bacteria: perspectives and challenges. Trends Biotechnol. 2003;21:269-74.

71. Zhou Y, Cui Y, Qu X. Exopolysaccharides of lactic acid bacteria: structure, bioactivity and associations: a review. Carbohydr Polym 2019;207:317-32

72. Panthavee W, Noda M, Danshiitsoodol N, Kumagai T, Sugiyama M. Characterization of exopolysaccharides produced by thermophilic lactic acid bacteria isolated from tropical fruits of Thailand. Biol Pharm Bull. 2017;40:621-9.

73. Patil P, Wadehra A, Munjal K, Behare P. Isolation of exopolysaccharides producing lactic acid bacteria from dairy products. Asian J Dairy Food Res. 2015:34:280-4.

74. Lule V, Singh R, Behare P, Tomar SK. Comparison of exopolysaccharide production by indigenous Leuconostoc mesenteroides strains in whey medium. Asian J Dairy Food Res. 2015;34:8-12.

75. Behare PV, Singh R, Nagpal R, Rao KH. Exopolysaccharides producing Lactobacillus fermentum strain for enhancing rheological and sensory attributes of low-fat dahi. J Food Sci Tech. 2013;50:1228-32.

76. Behare P, Singh R, Singh RP. Exopolysaccharide-producing mesophilic lactic cultures for preparation of fat-free dahi-an Indian fermented milk. J Dairy Res. 2009;76:90-7.

77. Fracchia L, Cavallo M, Allegrone G, Martinotti MG. A Lactobacillusderived biosurfactant inhibits biofilm formation of human pathogenic Candida albicans biofilm producers. Appl Microbiol Biotechnol. 2010;2:827-37.

78. Di W, Zhang L, Wang S, Yi H, Han X, Fan R, Zhang Y. Physicochemical characterization and antitumour activity of exopolysaccharides produced by Lactobacillus casei SB27 from yak milk. Carbohydr Polym. 2017;171:307-15.

79. Wang K, Niu M, Song D, Song X, Zhao J, Wu Y, Lu B, Niu G. Preparation, partial characterization and biological activity of exopolysaccharides produced from Lactobacillus fermentum S1. J Biosci Bioeng. 2019;129:206-14.

80. Xu R, Aruhan Xiu L, Sheng S, Liang Y, Zhang H, Liu Y, Tong H, Du R, Wang $X$. Exopolysaccharides from Lactobacillus buchneri TCP016 Attenuate LPS-and d-GalN-induced liver injury by modulating the gut microbiota. J Agr Food Chem. 2019;67:11627-37.

81. Xiaoqun, YBPDZ. Study on selenium modification and antioxidant activity of lactic acid bacteria exopolysaccharides. J Chin Inst Food Sci Technol. 2012; 2 .
82. Lebeer S, Claes IJ, Verhoeven TL, Vanderleyden J, De Keersmaecker SC. Exopolysaccharides of Lactobacillus rhamnosus $\mathrm{GG}$ form a protective shield against innate immune factors in the intestine. Microb Biotechnol. 2011;4:368-74.

83. Ruas-Madiedo P, Medrano M, Salazar N, De Los Reyes-Gavilán CG, Pérez PF, Abraham AG. Exopolysaccharides produced by Lactobacillus and Bifidobacterium strains abrogate in vitro the cytotoxic effect of bacterial toxins on eukaryotic cells. J Appl Microbiol. 2010;109:2079-86.

84. Siciliano RA, Lippolis R, Mazzeo MF. Proteomics for the investigation of surface-exposed proteins in probiotics. Front Nutr. 2019. https://doi. org/10.3389/fnut.2019.00052.

85. Frece J, Kos B, Svetec IK, Zgaga Z, Mrša V, Šušković J. Importance of S-layer proteins in probiotic activity of Lactobacillus acidophilus M92. J Appl Microbiol. 2005;98:285-92.

86. Das JK, Mahapatra RK, Patro S, Goswami C, Suar M. Lactobacillus acidophilus binds to MUC3 component of cultured intestinal epithelial cells with highest affinity. FEMS Microbiol Lett. 2016;363:050.

87. Li P, Yu Q, Ye X, Wang Z, Yang Q. Lactobacillus S-layer protein inhibition of Salmonella-induced reorganization of the cytoskeleton and activation of MAPK signalling pathways in Caco-2 cells. Microbiol. 2011;157:2639-46.

88. Liu Z, Shen T, Zhang P, Ma Y, Qin H. Lactobacillus plantarum surface layer adhesive protein protects intestinal epithelial cells against tight junction injury induced by enteropathogenic Escherichia coli. Mol Biol Rep. 2011;38:3471-80.

89. Pragya P, Kaur G. Ali SA, Bhatla S, Rawat P, Lule V, Kumar S, Mohanty AK, Behare P. High-resolution mass spectrometry-based global proteomic analysis of probiotic strains Lactobacillus fermentum. J Proteomics. 2017;152:121-130.

90. Kumar N, Kumar V, Panwar R, Ram C. Efficacy of indigenous probiotic Lactobacillus strains to reduce cadmium bioaccessibility-an in vitro digestion model. Environ Sci Pollut R. 2017;24:1241-50.

91. Johnson-Henry KC, Hagen KE, Gordonpour M, Tompkins TA, Sherman PM. Surface-layer protein extracts from Lactobacillus helveticus inhibit enterohaemorrhagic Escherichia coli O157: H7 adhesion to epithelial cells. Cell Microbiol. 2007;9:356-67.

92. Qin H, Zhang Z, Hang X, Jiang YL. plantarum prevents enteroinvasive Escherichia coli-induced tight junction proteins changes in intestinal epithelial cells. BMC Microbiol. 2009;9:63.

93. He Y, Xu X, Zhang F, Xu D, Liu Z, Tao X, Wei H. Anti-adhesion of probiotic Enterococcus faecium WEFA23 against five pathogens and the beneficial effect of its S-layer proteins against Listeria monocytogenes. Can J Microbiol. 2018;65:175-84.

94. Singh KS, Kumar S, Mohanty AK, Grover S, Kaushik JK. Mechanistic insights into the host-microbe interaction and pathogen exclusion mediated by the Mucus-binding protein of Lactobacillus plantarum. Sci Rep. 2018;8:14198.

95. Johnson BR, O'Flaherty S, Goh YJ, Carroll I, Barrangou R, Klaenhammer TR. The S-layer associated serine protease homolog PrtX impacts cell surface-mediated microbe-host interactions of Lactobacillus acidophilus NCFM. Front Microbial. 2017:8:1185.

96. Gao K, Wang C, Liu L, Dou X, Liu J, Yuan L, Zhang W, Wang H. Immunomodulation and signaling mechanism of Lactobacillus rhamnosus GG and its components on porcine intestinal epithelial cells stimulated by lipopolysaccharide. J Microbiol Immunol. 2017;50:700-13.

97. Sumrall ET, Shen Y, Keller AP, Rismondo J, Pavlou M, Eugster MR, Boulos $\mathrm{S}$, Disson $\mathrm{O}$, Thouvenot $\mathrm{P}$, Kilcher $\mathrm{S}$, Wollscheid B. Phage resistance at the cost of virulence: listeria monocytogenes serovar $4 \mathrm{~b}$ requires galactosylated teichoic acids for InIB-mediated invasion. PLoS Pathog. 2019:15:1-29.

98. Kattke M, Gosschalk J, Clubb R. Structural, biochemical, and cellular studies of TarA, the novel wall teichoic acid glycosyltransferase, for the discovery of gram-positive bacterial inhibitors. FASEBJ. 2017;2017(31):939-18.

99. Paganelli FL, van de Kamer T, Brouwer EC, Leavis HL, Woodford N, Bonten MJ, Willems RJ, Hendrickx AP. Lipoteichoic acid synthesis inhibition in combination with antibiotics abrogates growth of multidrugresistant Enterococcus faecium. Int J Antimicrob Ag. 2017:49:355-63.

100. Brown S, Maria SJP Jr, Walker S. Wall teichoic acids of gram-positive bacteria. Annu Rev Microbiol. 2013;67:313-36. 
101. Claes IJ, Segers ME, Verhoeven TL, Dusselier M, Sels BF, De Keersmaecker SC, Vanderleyden J, Lebeer S. Lipoteichoic acid is an important microbe-associated molecular pattern of Lactobacillus rhamnosus GG. Microb Cell Fact. 2012;11:161.

102. Shiraishi T, Yokota S, Fukiya S, Yokota A. Structural diversity and biological significance of lipoteichoic acid in gram-positive bacteria: focusing on beneficial probiotic lactic acid bacteria. Biosci Microb Food H. 2016;35:147-61.

103. Wang S, Ahmadi S, Nagpal R, Jain S, Mishra SP, Kavanagh K, Zhu X, Wang Z, McClain DA, Kritchevsky SB, Kitzman DW. Lipoteichoic acid from the cell wall of a heat killed Lactobacillus paracasei D3-5 ameliorates agingrelated leaky gut, inflammation and improves physical and cognitive functions: from C. elegans to mice. GeroScience. 2020;42:333-52.

104. Kim KW, Kang SS, Woo SJ, Park OJ, Ahn KB, Song KD, Lee HK, Yun CH, Han SH. Lipoteichoic acid of probiotic Lactobacillus plantarum attenuates poly I: C-induced IL-8 production in porcine intestinal epithelial cells. Front Microbiol. 2017;8:1827.

105. Ahn JE, Kim H, Chung DK. Lipoteichoic acid isolated from Lactobacillus plantarum maintains inflammatory homeostasis through regulation of Th1-and Th2 induced cytokines. J Microbiol Biotechnol. 2019;2019(29):151-9.

106. Jung S, Park OJ, Kim AR, Ahn KB, Lee D, Kum KY, Yun CH, Han SH. Lipoteichoic acids of lactobacilli inhibit Enterococcus faecalis biofilm formation and disrupt the preformed biofilm. J Microbiol. 2020;57:310-5.

107. Kim AR, Ahn KB, Yun CH, Park OJ, Perinpanayagam H, Yoo YJ, Kum KY, Han SH. Lactobacillus plantarum lipoteichoic acid inhibits oral multispecies biofilm. J Endod. 2019:4:310-5.

108. Ahn KB, Baik JE, Park OJ, Yun CH, Han SH. Lactobacillus plantarum lipoteichoic acid inhibits biofilm formation of Streptococcus mutans. PLOS ONE. 2018;13:0192694.

109. Ahn KB, Baik JE, Yun CH, Han SH. Lipoteichoic acid inhibits Staphylococcus aureus biofilm formation. Front Microbiol. 2018;9:327.

110. Vollmer W, Blanot D, De Pedro MA. Peptidoglycan structure and architecture. FEMS Microbiol Rev. 2008;32:149-67.

111. Chapot-Chartier MP, Kulakauskas S. Cell wall structure and function in lactic acid bacteria. Microb Cell Fact. 2014;13:S9.

112. Clua P, Kanmani P, Zelaya H, Tada A, Kober AKM, Salva S, Alvarez S, Kitazawa H, Villena J. Peptidoglycan from immunobiotic Lactobacillus rhamnosus improves resistance of infant mice to respiratory syncytial viral infection and secondary pneumococcal pneumonia. Front Immunol. 2017;2017(8):948.

113. Sekine K, Toida T, Saito M, Kuboyama M, Kawashima T, Hashimoto Y. A new morphologically characterized cell wall preparation (whole peptidoglycan) from Bifidobacterium infantis with a higher efficacy on the regression of an established tumor in mice. Cancer Res. 1985;45:1300-7.

114. Wang S, Han X, Zhang L, Zhang Y, Li H, Jiao Y. Whole peptidoglycan extracts from the Lactobacillus paracasei subsp. paracasei M5 strain exert anticancer activity in vitro. Biomed Res Int. 2018;2018:1-12.

115. Aintablian A, Jaber DF, Jallad MA, Abdelnoor AM. The effect of Lactobacillus plantarum and bacterial peptidoglycan on the growth of mouse tumors in vivo and in vitro. Am J Immunol. 2017;13:201-8.

116. Li X, Sun Q, Wang Y, Han D, Fan J, Zhang J, Yang C, Ma X, Sun Q. The regulatory effects of $L$. plantarum peptidoglycan microspheres on innate and humoral immunity in mouse. J Microencapsul. 2017;34:635-43.

117. Shida K, Kiyoshima-Shibata J, Kaji R, Nagaoka M, Nanno M. Peptidoglycan from lactobacilli inhibits interleukin-12 production by macrophages induced by Lactobacillus casei through toll-like receptor 2-dependent and independent mechanisms. Immunol. 2009;128:858-e869.

118. Kapustian Al, Cherno N, Kovalenko A, Naumenko K, Kushnir I. Products of metabolism and processing of lactic acid bacteria as functional ingredients. Food Sci Biotechnol. 2018;1:47-55.

119. Schwenninger SM, Lacroix C, Truttmann S, Jans C, Spoerndli C, Bigler L, Meile L. Characterization of low-molecular-weight antiyeast metabolites produced by a food-protective Lactobacillus-Propionibacterium coculture. J Food Prot. 2008;71:2481-7.

120. Siedler S, Balti R, Neves AR. Bioprotective mechanisms of lactic acid bacteria against fungal spoilage of food. Curr Opin Biotech. 2019;56:138-46.

121. Foo HL, Loh TC, Abdul Mutalib NE, Rahim RA. The myth and therapeutic potentials of postbiotics. In: Faintuch J, Faintuch S, editors. Microbiome and metabolome in diagnosis, therapy, and other strategic applications. Cambridge: Academic Press; 2019. p. 201-8.

122. Saadatzadeh A, Fazeli MR, Jamalifar H, Dinarvand R. Probiotic properties of lyophilized cell free extract of Lactobacillus casei. Jundishapur J Nat Pharm Prod. 2013:8:131

123. Chuah LO, Foo HL, Loh TC, Alitheen NBM, Yeap SK, Mutalib NEA, Rahim RA, Yusoff K. Postbiotic metabolites produced by Lactobacillus plantarum strains exert selective cytotoxicity effects on cancer cells. BMC Complement Altern Med. 2019;19:114.

124. Moradi M, Mardani K, Tajik H. Characterization and application of postbiotics of Lactobacillus spp. on Listeria monocytogenes in vitro and in food models. LWT-Food Sci Technol. 2019;111:457-64.

125. Rodríguez-Pazo N, Vázquez-Araújo L, Pérez-Rodríguez N, CortésDiéguez S, Domínguez JM. Cell-free supernatants obtained from fermentation of cheese whey hydrolyzates and phenylpyruvic acid by Lactobacillus plantarum as a source of antimicrobial compounds, bacteriocins, and natural aromas. Appl Biochem Biotech. 2013;171:1042-60.

126. Wan MLY, Chen Z, Shah NP, El-Nezami H. Effects of Lactobacillus rhamnosus GG and Escherichia coli Nissle 1917 cell-free supernatants on modulation of mucin and cytokine secretion on human intestinal epithelial HT29-MTX Cells. J Food Sci. 2018;83:1999-2007.

127. De Marco S, Sichetti M, Muradyan D, Piccioni M, Traina G, Pagiotti R, Pietrella D. Probiotic cell-free supernatants exhibited anti-inflammatory and antioxidant activity on human gut epithelial cells and macrophages stimulated with LPS. Evid Based Complement Alternat Med. 2018;2018:1-12.

128. Alvarez CS, Giménez R, Cañas MA, Vera R, Díaz-Garrido N, Badia J, Baldomà L. Extracellular vesicles and soluble factors secreted by Escherichia coli Nissle 1917 and ECOR63 protect against enteropathogenic E. coli-induced intestinal epithelial barrier dysfunction. BMC Microbiol. 2019;19:166.

129. Rajoka MSR, Zhao H, Mehwish HM, Li N, Lu Y, Lian Z, Shao D, Jin M, Li Q, Zhao L, Shi J. Anti-tumor potential of cell free culture supernatant of Lactobacillus rhamnosus strains isolated from human breast milk. Food Res Int. 2019;123:286-97.

130. Kim Y, Whang JY, Whang KY, Oh S, Kim SH. Characterization of the cholesterol-reducing activity in a cell-free supernatant of $\mathrm{Lac}$ tobacillus acidophilus ATCC 43121. Biosci Biotechnol Biochem. 2008;72:0804300862-0804300862.

131. De Marco S, Sichetti M, Muradyan D, Piccioni M, Traina G, Pagiotti R, Pietrella D. Probiotic cell-free supernatants exhibited anti-inflammatory and antioxidant activity on human gut epithelial cells and macrophages stimulated with LPS. Evid Based Complementary Alternative Med. 2018;2018:1-12.

132. Singh N, Kaur R, Singh BP, Rokana N, Goel G, Puniya AK, Panwar H. Impairment of Cronobacter sakazakii and Listeria monocytogenes biofilms by cell-free preparations of lactobacilli of goat milk origin. Folia Microbiol. 2019;65:85-196.

133. Cui X, Shi Y, Gu S, Yan X, Chen H, Ge J. Antibacterial and antibiofilm activity of lactic acid bacteria isolated from traditional artisanal milk cheese from Northeast China against enteropathogenic bacteria. Probiotics Antimicrob Proteins. 2018;10:601-10.

134. Dey DK, Khan I, Kang SC. Anti-bacterial susceptibility profiling of Weissella confusa DD_A7 against the multidrug-resistant ESBL-positive E. coli. Microb Pathogenesis. 2019;128:119-30.

135. Zamani H, Rahbar S, Garakoui SR, Afsah Sahebi A, Jafari H. Antibiofilm potential of Lactobacillus plantarum spp. cell free supernatant (CFS) against multidrug resistant bacterial pathogens. Pharm Biomed Res. 2017;3:39-44.

136. Hussein AR, Khalaf ZZ, Samir Z, Samir R. Antibacterial activity of crude bacteriocin-like substance against food borne bacterial pathogens. Iraqi J Sci. 2018:59:16-24.

137. Drider D, Bendali F, Naghmouchi K, Chikindas ML. Bacteriocins: not only antibacterial agents. Probiotics Antimicrob Proteins. 2016;8:177-82.

138. Shakeel A, Saeed M, Randhawa MA, Zia MA. Isolation and characterization of bacteriocinogenic lactic acid bacteria from indiginous dairy source and its antimicrobial potential. Pak J Agr Sci. 2018;55:175-82.

139. Field D, Ross RP, Hill C. Developing bacteriocins of lactic acid bacteria into next generation biopreservatives. Curr Opin Food Sci. 2018;20:1-6. 
140. Alvarez-Sieiro P, Montalbán-López M, Mu D, Kuipers OP. Bacteriocins of lactic acid bacteria: extending the family. Appl Microbiol Biotechnol. 2016;100:2939-51.

141. Malik RK, Kaur G. Biopreservation of dairy products: Role of bacteriocins of lactic acid bacteria. Chemical analysis of value added dairy products and their quality assurance. 2011:126.(CAFT).

142. Mokoena MP. Lactic acid bacteria and their bacteriocins: classification, biosynthesis and applications against uropathogens: a mini-review. Molecules. 2017;22:1255.

143. Martinez RCR, Alvarenga VO, Thomazini M, Fávaro-Trindade CS, de Souza Sant'Ana A. Assessment of the inhibitory effect of free and encapsulated commercial nisin (Nisaplin ${ }^{\circledR}$ ), tested alone and in combination, on Listeria monocytogenes and Bacillus cereus in refrigerated milk. LWT-Food Sci Technol. 2016;68:67-75.

144. Le Lay C, Fernandez B, Hammami R, Ouellette M, Fliss I. On Lactococcus lactis UL719 competitivity and nisin (Nisaplin ${ }^{\circledR}$ ) capacity to inhibit Clostridium difficile in a model of human colon. Front Microbiol. 2015;6:1020.

145. Makhal S, Kanawjia SK, Giri A. Effect of microGARD on keeping quality of direct acidified Cottage cheese. J Food Sci Tech. 2015:52:936-43.

146. Hasan FB, Reza M, Al Masud HA, Uddin MK, Uddin MS. Preliminary characterization and inhibitory activity of bacteriocin like substances from Lactobacillus casei against multi-drug resistant bacteria. Bangladesh J Microbiol. 2019;36:1-6.

147. Abanoz HS, Kunduhoglu B. Antimicrobial activity of a bacteriocin produced by Enterococcus faecalis KT11 against some pathogens and antibiotic-resistant bacteria. Korean J Food Sci An. 2018;38:1064

148. Gibson GR, Hutkins R, Sanders ME, Prescott SL, Reimer RA, Salminen SJ, Scott K, Stanton C, Swanson KS, Cani PD, Verbeke K. Expert consensus document: the International Scientific Association for Probiotics and Prebiotics (ISAPP) consensus statement on the definition and scope of prebiotics. Nat Rev Gastro Hepat. 2017;14:491.

149. LeBlanc JG, Chain F, Martín R, Bermúdez-Humarán LG, Courau S, Langella P. Beneficial effects on host energy metabolism of short-chain fatty acids and vitamins produced by commensal and probiotic bacteria. Microb Cell Fact. 2017;16:79.

150. Hijova E, Chmelarova A. Short chain fatty acids and colonic health. Bratisl Med J. 2007:108:354.

151. Zeng H, Umar S, Rust B, Lazarova D, Bordonaro M. Secondary bile acids and short chain fatty acids in the colon: a focus on colonic microbiome cell proliferation, inflammation, and cancer. Int J Mol Sci. 2019;20:1214.

152. Fernández J, Redondo-Blanco S, Gutiérrez-del-Río I, Miguélez EM, Villar CJ, Lombó F. Colon microbiota fermentation of dietary prebiotics towards short-chain fatty acids and their roles as anti-inflammatory and antitumour agents: a review. J Funct Foods. 2016;25:511-22.

153. Nagpal R, Wang S, Ahmadi S, Hayes J, Gagliano J, Subashchandrabose S, Kitzman DW, Becton T, Read R, Yadav H. Human-origin probiotic cocktail increases short-chain fatty acid production via modulation of mice and human gut microbiome. Sci Rep. 2018:8:12649.

154. White, K. Effects of short-chain fatty acids propionate, acetate, butyrate on the growth of Clostridium difficile in Co-culture with an Escherichia coli atoE Mutant. 2017. Master's Thesis, Texas State University. https:// digital.library.txstate.edu/handle/10877/6789. Accessed 15 July 2020.

155. Ribeiro WR, Vinolo MAR, Calixto LA, Ferreira CM. Use of Gas Chromatography to quantify short chain fatty acids in the serum, colonic luminal content and feces of mice. Bio-protocol. 2018;2018(8):1-11.

156. Venegas DP, Marjorie K, Landskron G, González MJ, Quera R, Dijkstra G, Harmsen HJ, Faber KN, Hermoso MA. Short Chain Fatty Acids (SCFAs)mediated gut epithelial and immune regulation and its relevance for Inflammatory Bowel Diseases. Front Immunol. 2019;10:227.

157. Cremon C, Guglielmetti S, Gargari G, Taverniti V, Castellazzi AM, Valsecchi C, Tagliacarne C, Fiore W, Bellini M, Bertani L, Gambaccini D. Effect of Lactobacillus paracasei CNCM I-1572 on symptoms, gut microbiota, short chain fatty acids, and immune activation in patients with irritable bowel syndrome: a pilot randomized clinical trial. United Eur Gastroent J. 2018;6:604-13.

158. Zheng L, Kelly CJ, Battista KD, Schaefer R, Lanis JM, Alexeev EE, Wang RX, Onyiah JC, Kominsky DJ, Colgan SP. Microbial-derived butyrate promotes epithelial barrier function through IL-10 receptor-dependent repression of claudin-2. J Immunol. 2017;199:2976-84.
159. Miao W, Wu X, Wang K, Wang W, Wang Y, Li Z, Liu J, Li L, Peng L. Sodium butyrate promotes reassembly of tight junctions in Caco-2 monolayers involving inhibition of MLCK/MLC2 pathway and phosphorylation of PKCß2. Int J Mol Sci. 2016;17:1696.

160. Valenzano MC, DiGuilio K, Mercado J, Teter M, To J, Ferraro B, et al. Remodeling of tight junctions and enhancement of barrier integrity of the Caco-2 intestinal epithelial cell layer by micronutrients. PLoS ONE. 2015;10:e0133926.

161. Peng L, Li Z-R, Green RS, Holzman IR, Lin J. Butyrate enhances the intestinal barrier by facilitating tight junction assembly via activation of AMP-activated protein kinase in Caco-2 cell monolayers. J Nutr. 2009:139:1619-25.

162. de Giori GS, LeBlanc JG. Folate production by lactic acid bacteria. In: Watson RR, Preedy VR, Zibadi S, editors. Polyphenols: prevention and treatment of human disease. Cambridge: Acadmeic Press; 2018. p. $15-29$.

163. Thakur K, Tomar SK. In vitro study of riboflavin producing lactobacilli as potential probiotic. LWT-Food Sci Technol. 2016;68:570-8.

164. Deptula P, Chamlagain B, Edelmann M, Sangsuwan P, Nyman TA, Savijoki K, Piironen V, Varmanen P. Food-like growth conditions support production of active vitamin B12 by Propionibacterium freudenreichii 2067 without DMBI, the lower ligand base, or cobalt supplementation. Front Microbiol. 2017;8:368.

165. Jayashree S, Jayaraman K, Kalaichelvan G. Isolation, screening and characterization of riboflavin producing lactic acid bacteria from Katpadi, Vellore district. Rec Res Sci Tech. 2010;2:83-8.

166. Magnúsdóttir S, Ravcheev D, de Crécy-Lagard V, Thiele I. Systematic genome assessment of B-vitamin biosynthesis suggests co-operation among gut microbes. Fronti Genet. 2015;6:148.

167. Thakur K, Lule VK, Rajni CS, Kumar N, Mandal S, Anand S, Kumari V, Tomar SK. Riboflavin producing probiotic lactobacilli as a biotechnological strategy to obtain riboflavin-enriched fermented foods. J Pure Appl Microbiol. 2016;10:161-6.

168. Thakur K, Tomar SK, De S. Lactic acid bacteria as a cell factory for riboflavin production. Microb Biotechnol. 2016;9:441-51.

169. Bardosono S, Wibowo N, Sutanto LB, Irwinda R, Cannan R, Rowan A, Dekker J. Plasma folate, vitamin B6 and B12 in their relationship to the presence of probiotic strain Bifidobacterium animalis subsp. Lactis HNO19 (DR10TM) among Indonesian pregnant women in their third semester. World Nutr J. 2019;2:56-62.

170. Ueno N, Fujiya M, Segawa S, Nata T, Moriichi K, Tanabe H, Mizukami Y, Kobayashi N, Ito K, Kohgo Y. Heat-killed body of Lactobacillus brevis SBC8803 ameliorates intestinal injury in a murine model of colitis by enhancing the intestinal barrier. Inflamm Bowel Dis. 2011;17:2235-50.

171. Merghni A, Dallel I, Noumi E, Kadmi Y, Hentati H, Tobji S, Amor AB, Mastouri M. Antioxidant and antiproliferative potential of biosurfactants isolated from Lactobacillus casei and their anti-biofilm effect in oral Staphylococcus aureus strains. Microb pathogenesis. 2017;104:84-9.

172. Pereira JF, Gudiña EJ, Costa R, Vitorino R, Teixeira JA, Coutinho JA, Rodrigues LR. Optimization and characterization of biosurfactant production by Bacillus subtilis isolates towards microbial enhanced oil recovery applications. Fuel. 2013;111:259-68.

173. Carasi P, Trejo FM, Pérez PF, De Antoni GL, De los Serradell AM. Surface proteins from Lactobacillus kefir antagonize in vitro cytotoxic effect of Clostridium difficile toxins. Anaerobe. 2012;18:135-42.

174. Li N, Russell WM, Douglas-Escobar M, Hauser N, Lopez M, Neu J. Live and heat-killed Lactobacillus rhamnosus GG: effects on proinflammatory and anti-inflammatory cytokines/chemokines in gastrostomy-fed infant rats. Pediatr Res. 2009;66:203.

175. Biswas G, Korenaga H, Nagamine R, Takayama H, Kawahara S, Takeda S, Kikuchi Y, Dashnyam B, Kono T, Sakai M. Cytokine responses in the Japanese pufferfish (Takifugu rubripes) head kidney cells induced with heat-killed probiotics isolated from the Mongolian dairy products. Fish Shellfish immune. 2013;34:1170-7.

176. Sang LX, Chang B, Dai C, Gao N, Liu WX, Jiang M. Heat-killed VSL\# 3 ameliorates dextran sulfate sodium (DSS)-induced acute experimental colitis in rats. Int J Mol Sci. 2014;15:15-28.

177. Ciandrini E, Campana R, Baffone W. Live and heat-killed Lactobacillus spp. interfere with Streptococcus mutans and Streptococcus oralis during biofilm development on titanium surface. Arch Oral Biol. 2017:78:48-57. 
178. Escamilla J, Lane MA, Maitin V. Cell-free supernatants from probiotic Lactobacillus casei and Lactobacillus rhamnosus GG decrease colon cancer cell invasion in vitro. Nutr Cancer. 2012;64:871-8.

179. Abbas HH, Abudulhadi S, Mohammed A, Shawkat DS, Baker YM. Effect of Lactobacillus sp. crude bacteriocin (CB) and cell-free supernatant (CFS) against E. coli growth and adherence on vaginal epithelial cell surface. Int J Adv Res. 2016;4:614-20.

180. Rishi L, Mittal G, Agarwal RK, Sharma T. Melioration in anti-staphylococcal activity of conventional antibiotic (s) by organic acids present in the cell free supernatant of Lactobacillus paraplantarum. Indian J Microbiol. 2017;57:359-64.

181. Koscik RJ, Reid G, Kim SO, Li W, Challis JR, Bocking AD. Effect of Lactobacillus rhamnosus GR-1 supernatant on cytokine and chemokine output from human amnion cells treated with lipoteichoic acid and lipopolysaccharide. Reprod Sci. 2018;25:239-45.

182. He X, Zeng Q, Puthiyakunnon S, Zeng Z, Yang W, Qiu J, Du L, Boddu S, Wu T, Cai D, Huang SH. Lactobacillus rhamnosus GG supernatant enhance neonatal resistance to systemic Escherichia coli K1 infection by accelerating development of intestinal defense. Sci Rep. 2017;2017(7):43305

183. Lv C, Jia F, Wang D, Ding J, Fang L. Insights into the suppression of multidrug-resistant Helicobacter pylori by probiotics supernatant. Jundishapur J Microbiol. 2019;12:e91797.

184. Lim HS, Yeu JE, Hong SP, Kang MS. Characterization of antibacterial cell-free supernatant from oral care probiotic Weissella cibaria. Molecules. 2018;23:1984.

185. Kumar R, Sharma A, Gupta M, Padwad Y, Sharma R. Cell-free culture supernatant of probiotic Lactobacillus fermentum protects against H2O2-induced premature senescence by suppressing ROS-AktmTOR axis in murine preadipocytes. Probiotics Antimicrob Proteins. 2020;12:563-76.

186. Tok E, Aslim B. Cholesterol removal by some lactic acid bacteria that can be used as probiotic. Microbiol Immunol. 2010;54:257-64.

187. Lindström C, Holst O, Nilsson L, Öste R, Andersson KE. Effects of Pediococcus parvulus 2.6 and its exopolysaccharide on plasma cholesterol levels and inflammatory markers in mice. AMB Express. 2012;2:66.

188. Sarikaya H, Aslim B, Yuksekdag Z. Assessment of anti-biofilm activity and bifidogenic growth stimulator (BGS) effect of lyophilized exopolysaccharides (I-EPSs) from lactobacilli strains. Int J Food Prop. 2017:20:362-71.

189. Wang K, Niu M, Song D, Song X, Zhao J, Wu Y, Lu B, Niu G. Preparation, partial characterization and biological activity of exopolysaccharides produced from Lactobacillus fermentum S1. J Biosci Bioeng. 2019;129:26-214

190. Merghni A, Dallel I, Noumi E, Kadmi Y, Hentati H, Tobji S, Amor AB, Mastouri M. Antioxidant and antiproliferative potential of biosurfactants isolated from Lactobacillus casei and their anti-biofilm effect in oral Staphylococcus aureus strains. Microb Pathog. 2017;104:84-9.

191. Emmanuel EC, Priya SS, George S. Isolation of biosurfactant from Lactobacillus sp. and study of its inhibitory properties against E. coli biofilm. J Pure Appl Microbiol. 2019:3:403-11.

192. Giordani B, Costantini PE, Fedi S, Cappelletti M, Abruzzo A, Parolin C, Foschi C, Frisco G, Calonghi N, Cerchiara T, Bigucci F. Liposomes containing biosurfactants isolated from Lactobacillus gasseri exert antibiofilm activity against methicillin resistant Staphylococcus aureus strains. Eur J Pharm Biopharm. 2019;139:246-52.

193. Gao Q, Gao Q, Min M, Zhang C, Peng S, Shi Z. Ability of Lactobacillus plantarum lipoteichoic acid to inhibit Vibrio anguillarum-induced inflammation and apoptosis in silvery pomfret (Pampus argenteus) intestinal epithelial cells. Fish Shellfish Immun. 2016;54:573-9.

194. Jeon B, Kim HR, Kim H, Chung DK. In vitro and in vivo downregulation of C3 by lipoteichoic acid isolated from Lactobacillus plantarum K8 suppressed cytokine-mediated complement system activation. FEMS Microbiol Lett. 2016;363:1-6.

195. Fichera GA, Fichera M, Milone G. Antitumoural activity of a cytotoxic peptide of Lactobacillus casei peptidoglycan and its interaction with mitochondrial-bound hexokinase. Anti-Cancer Drug. 2016;27:609.

196. Kolling Y, Salva S, Villena J, Alvarez S. Are the immunomodulatory properties of Lactobacillus rhamnosus CRL1505 peptidoglycan common for all lactobacilli during respiratory infection in malnourished mice? PLOS ONE. 2018:13:0194034.
197. Ramiah K, van Reenen CA, Dicks LM. Surface-bound proteins of Lactobacillus plantarum 423 that contribute to adhesion of Caco-2 cells and their role in competitive exclusion and displacement of Clostridium sporogenes and Enterococcus faecalis. Res Microbiol. 2008;159:470-5.

198. Guo Y, Jiang X, Yang Y, Zhang J, Zeng X, Wu Z, Sun Y, Pan D. Prevention of necrotizing enterocolitis through surface layer protein of Lactobacillus acidophilus CICC6074 reducing intestinal epithelial apoptosis. J Func Foods. 2018;47:91-9.

199. Vemuri R, Gundamaraju R, Shinde T, Perera AP, Basheer W, Southam B, Gondalia SV, Karpe AV, Beale DJ, Tristram S, Ahuja KD. Lactobacillus acidophilus DDS-1 modulates intestinal-specific microbiota, shortchain fatty acid and immunological profiles in aging mice. Nutrients. 2019;2019(11):1297.

200. Nagpal R, Wang S, Ahmadi S, Hayes J, Gagliano J, Subashchandrabose S, Kitzman DW, Becton T, Read R, Yadav H. Human-origin probiotic cocktail increases short-chain fatty acid production via modulation of mice and human gut microbiome. Sci Rep. 2018;8:649.

201. Dai S, Pan M, El-Nezami HS, Wan JM, Wang MF, Habimana O, Lee JC, Louie JC, Shah NP. Effects of lactic acid bacteria-fermented soymilk on isoflavone metabolites and short-chain fatty acids excretion and their modulating effects on gut microbiota. J Food Sci. 2019;8:1854-63.

202. Hsieh CY, Osaka T, Moriyama E, Date Y, Kikuchi J, Tsuneda S. Strengthening of the intestinal epithelial tight junction by Bifidobacterium bifidum. Physiol Rep. 2015;3:e12327.

203. Laiño JE, LeBlanc JG, de Giori SG. Production of natural folates by lactic acid bacteria starter cultures isolated from artisanal Argentinean yogurts. Can J Microbiol. 2012;58:581-8.

204. Xie C, Coda R, Chamlagain B, Varmanen P. Co-fermentation of Propionibacterium freudenreichii and Lactobacillus brevis in wheat bran for in situ production of vitamin B12. Front Microbiol. 2019:2019(10):1541.

205. Patil S, Sawant S, Hauff K, Hampp G. Validated postbiotic screening confirms presence of physiologically-active metabolites, such as short-shain fatty acids, amino acids and vitamins in Hylak ${ }^{\circledR}$ Forte. Probiotics Antimicrob Proteins. 2019;11:1124-31.

206. Ruiz-Moyano S, dos Santos MTPG, Galván Al, Merchán AV, González E, de Guía Córdoba M, Benito MJ. Screening of autochthonous lactic acid bacteria strains from artisanal soft cheese: probiotic characteristics and prebiotic metabolism. LWT-Food Sci Technol. 2019;114:08388.

207. Chamlagain B, Sugito TA, Deptula P, Edelmann M, Kariluoto S, Varmanen P, Piironen V. In situ production of active vitamin B12 in cereal matrices using Propionibacterium freudenreichii. Food Sci Nut. 2018;6:67-76.

208. Wichienchot S, Hemmaratchirakul J, Jaturapiree P, Pruksasri S. Evaluating prebiotic property of galactooligosaccharide produced by Lactobacillus pentosus var. plantarum BFP32 in fecal batch culture. Int Food Res J. 2016;23:2241-8.

209. Bhushan B, Tomar SK, Mandal S. Phenotypic and genotypic screening of human-originated lactobacilli for vitamin B-12 production potential: process validation by micro-assay and UFLC. Appl Microbiol Biotechnol. 2016;2016(100):6791-803.

210. Masuda M, Ide M, Utsumi H, Niiro T, Shimamura Y, Murata M. Production potency of folate, vitamin B12, and thiamine by lactic acid bacteria isolated from japanese pickles. Biosci Biotechnol Biochem. 2012;76:2061-7.

211. Hugenschmidt S, Schwenninger SM, Gnehm N, Lacroix C. Screening of a natural biodiversity of lactic and propionic acid bacteria for folate and vitamin B12 production in supplemented whey permeate. Int Dairy J. 2010;20:852-7.

212. Wang C, Shoji H, Sato H, Nagata S, Ohtsuka Y, Shimizu T, Yamashiro Y. Effects of oral administration of Bifidobacterium breve on fecal lactic acid and short-chain fatty acids in low birth weight infants. J Pediatr Gastroenterol Nutr. 2007;44:252-7.

\section{Publisher's Note}

Springer Nature remains neutral with regard to jurisdictional claims in published maps and institutional affiliations. 